Historic, Archive Document

Do not assume content reflects current scientific knowledge, policies, or practices. 



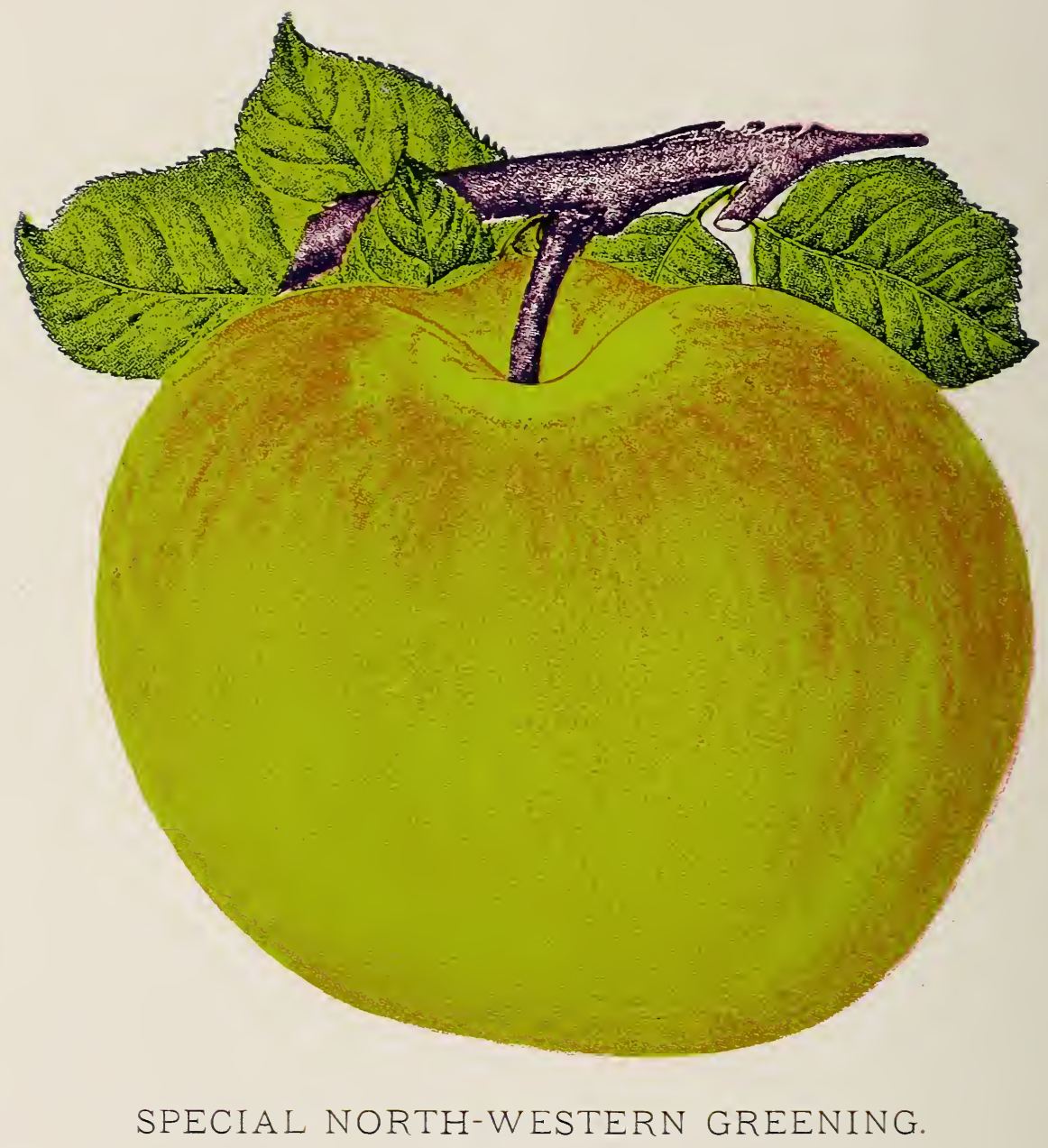

(See page 6.) 


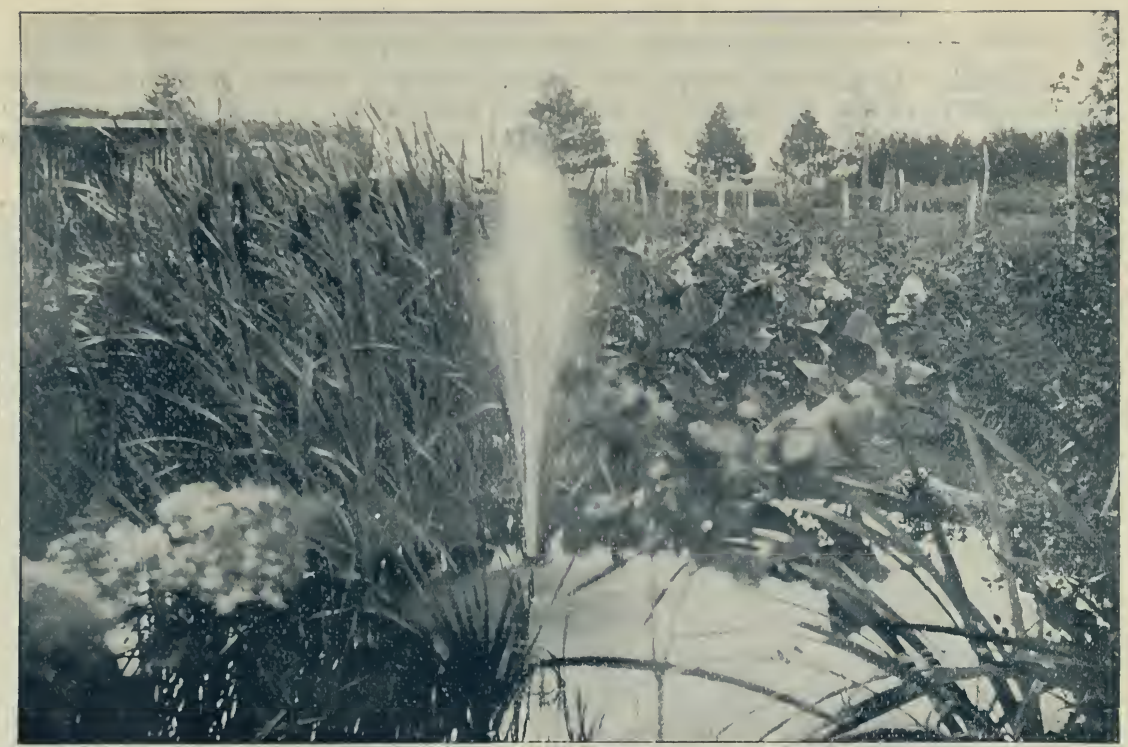

A view in our Nursery Park, showing a little nook in our out-door flower department. Here is to be found all sorts of Shrubs, Roses, Clematis and other hardy flowers.

Our Location, as will be secu by the map, is in the extreme northern part of Iowa, but 15 miles from the Minnesota State line, and where the

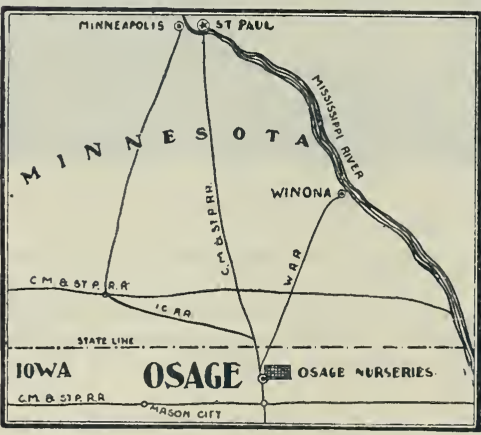

thermometer often Mestown to 40 and 50 degrees belor zero during the winter months. Our nursery ground are all located on what was originally virgin prairie, without shelter from any direction by natural timber Since the establishment of our NURSERIES in 1869 our coustant aim has becn to produce HARDY TREES on HARDY ROOTS-trees that would succeed in the cold north. Our success has been very gratifying and far beyond our fondest dreams. We can now look over the broad prairies of the nortl west and see scattered here and there, large orchards, surrounded by Evergreen and Deciduous wind-brcaks; fine plantations of small fruits; beantiful ormament als, ete , etc., all helping to make happier the home lifo, besides bringing in large substantial returns from fruit sold. To know that we have been responsible in no small measure for transforming parts of what was but a short time ago called the Great American Descrt, into veritable Edens of paradise, brings to us a happiness that money could not bny. We love our work and onr constant endeavor is to improve on present Hardy Varicties and by eross fertilization and seed selection, to secure others of still hardier strains and of still better fruiting powers. Our soil is especially allapted for growing a strong, vigorons tree, and witl our most exeellent R. R. facilities, we are in the hest location in the United States to furnish you with HARI)Y, IRON-CLAI) mursery stock, stock that will withstand sudden ehanges of temperature (we have had 60 desrec shanse iuside of ten hours), severe drouth and excessive moisture, without being injured therebs. We had over $10,000,000$ of trees, plauts alid vines which stood in our murseries during the test winter of 189s-9, and we dicl not lose as single tree by reason of injury to roots.

CHEAP STOCK.-While our prices will be found to be much lower than those asked by $n$ llirsery agents, still we do not pretencl to compete with "CHEAP STOCK" prices. We believe that hardy stock, propagated hy the best niethods and grown in our environments is worth from 10\% to $100 \%$ more to the planter, whether living in the extreme north or south. than stock grown in ally other locality in the United States. Onr reasons for this belief are: 1st-Northern grown trees produce the finest fruit. It is an undisputed fact that the farther north certain fruit is grown the finer the flavor. 2nd.-No other trees are so hardy or as vigorous growers or come into bearing so early. Our seasons are such that the trees always ripen their wood thoroughly each fall, and in doing so store up a large amount of vitality, enabling them to bear the shock of transplanting without injirry, even under unfa vorable corsditions. 3rd.-Our trees willGROW and BEAR FRUIT of the finest quality and give the inost satisfactory all-around results to the person who plants them. 


\section{BUDDED TREES.}

The $e^{-}$difference between budded trees and root-grafted trees is this, that in budding, the bud is put in at the surface of the ground, thus making the tree absolutely dependent upon the stock or seedling root for its support, having no possibe chance of throwing out roots of the variety of the bud. All it needs to kill such a tree, even if it has pulled through for 12 or 15 years, is to have a test winter like the one of 1898-99. Thousands of dollars were lost to the planters, more especially in the south, (for there is the home of the budded tree), from the effects of that not-soon-to-be-forgotten winter. Had the trees been on own roots it great deal of the damage would not have occurred.

\section{FRUIT DEPARTMENT.}

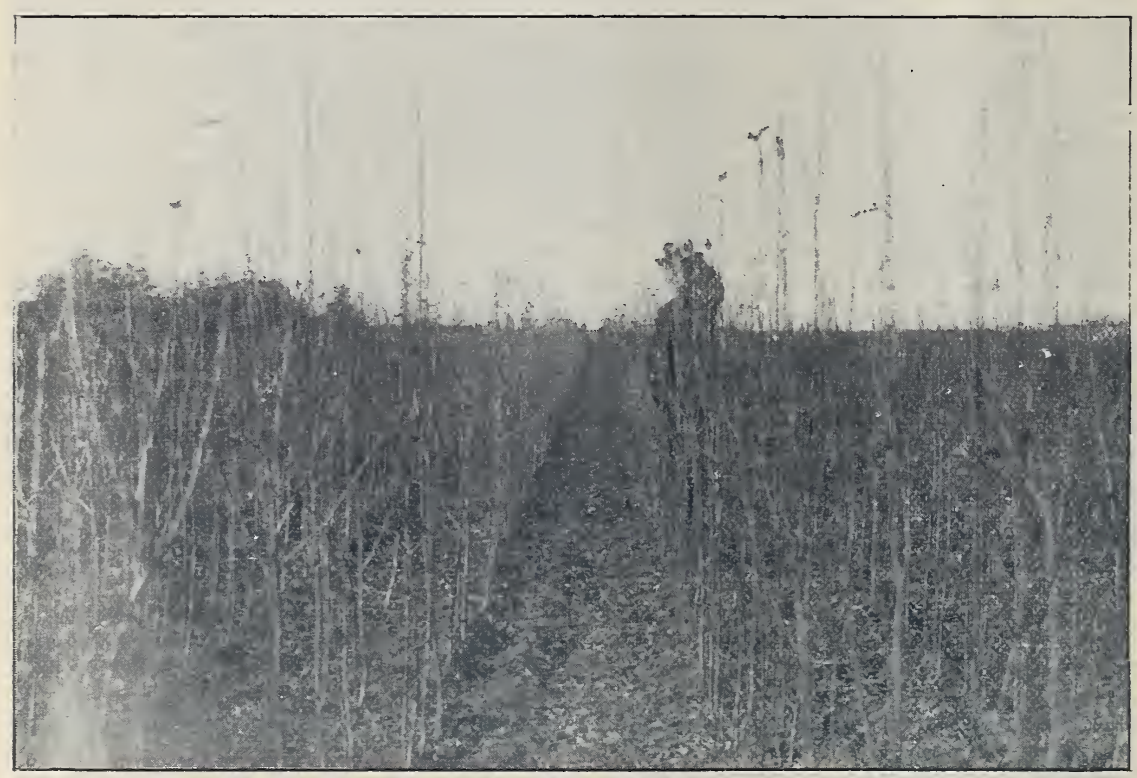

A PHOTO PLATE OF A BLOCK OF OUR LONG SCION APPLE TREES. WE HAVE ABOUT 150,000 TREES READY TO DIG FOR SPRING AND FALL, 1901.

\section{APPLES.}

The King of Fruits.-There is no state or territory in which it cannot be grown with success. Out of 150 varieties growing on our grounds we select only the following varieties which we can recommend for general planting, feeling sure that they will give the best of satisfaction either for the commercial orchard or for the home garden. No farm should be without its orchard. No other investment pays as does the orchard. More money is made from one to five acres in orchard than from ten to fifty acres used for general purposes. We know of one farmer who got at least $\$ 10.00$ more per acre for his farm by reason of having a five-acre orchard on his farm. The orchard cost this man about $\$ 200.00$ and his place sold for $\$ 1600.00$ more than neighboring farms were offered at; besides he had already received from fruit sold more than the orchard had cost him. BE WISE and plant Hardy Northern Grown Trees.

Prices for common varieties of apple trees, all Long Scionstock, the very best grown, as follows, except where noted:

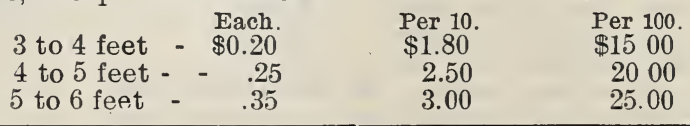




\section{The following Key will assist in selecting varieties suitable for different grades:}

$\mathbf{N}$ after name of variety, are those we recommend for the extreme north.

II after name of variety, are those not quite hardy in the extreme north.

$\mathbf{S}$ after name of variety, are those suitable only for southern planting.

Extreme northern planters should choose only from the N's. Southern planters will find profitable varieties in the N's and M's, as well as in the S's.

\section{SUMMER AND FALI VARIETIES.}

Duchess of Oldenburg $(\mathbf{N})-\mathrm{M}$ ed i $\mathrm{u} \mathrm{m}$ t o large size, streaked and shaded red; juicy, sprightly and sharp sub-acid. Tree hardiest grown. Russian origin. Season early fall.

Yellow Transparent ( $\mathbf{N})$-Another Russian of medium size, roundish, slightly conical; skin pale yellow when fully mature; flesh tender, juicy; sprightly, sub-acid. Early fall.

Tetofsky ( $\mathbf{N})$-A handsome R us sian apple, very hardy and productive; an early bearer ; fruit medium to large ; yellow striped with red. Late summer. Acid.

Red Astrachan ( $\boldsymbol{M})$-Large, roundish, nearly covered with deep crimson, overspread with a thick bloom; juicy; rich; acid; a good bearer and well liked. Early fall.

Early Harvest (M)-Medium size, roundish, straw color. Tender and subacid. Very productive. Late summer.

\section{WINTER VARIETIES.}

Walbridge $(\mathbf{N})$ - Medium size; striped witl red, handsome and of excellent quality. Vigorous grower and productive; very hardy and of great value in the north and northwest. March to June.

Winesap $(\boldsymbol{M})$ - Medium; dark red; sub-acid excellent Tree a moderate grower and abundant bearer. A favorite Inarket variety. Deccmber to May.

York Imperial ( $\mathbf{M})$-Mredium to large; jellow, shaded red: firm, juicy, sub-acid. An excellent shipping apple

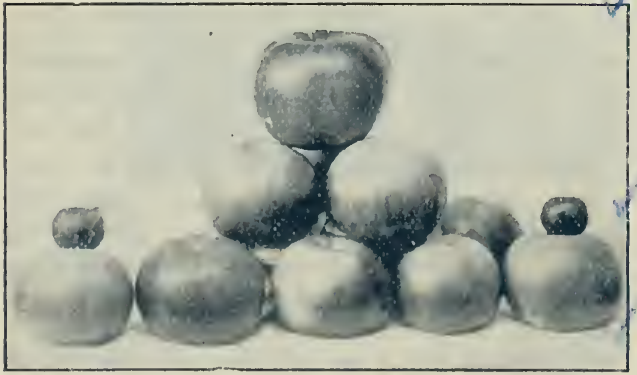

Crroup of apples as grown on our long seion trees. Largest weighed $23 \mathrm{ozs}$.

Talman's Sweeting ( $\mathbf{M})$ - Medium; pale $5 * 1-$ low, slightly tinged with red; firm, rich and very sweet. The most valualule baking apjle: vigorous and productive. November to April.

Ben Davis (S) - $\mathbf{A}$ lare, handsome striped apple of good quality; trec very hards, vigorous and productive: a late keeper; highly esteemed in the south-west.

Mclntosh Red ( $\mathbf{N})$ - An cxcecdingly valuable, hardy, Canarla sort; medium size, nearly covered with dark red; flesh white, tine, very tender, juicy and refreshing A good annual bearer of fair handsome fruit. Resembles the Faneuse, hut is larger and morc hardy, and fully equal in quality to this standard sort. Norembrer to February.
Pewaukee (N) - A seedling from Duchess of Oldenburg. Fruit medium to large, ovate; surface bright yellow, partially covered with dull red, striped and splashed, covered with a gray bloom and overspread with whitisl dots; cavity small; basin shallow and slightly fluted; calyx rather large; core small; flesh ycllowish white, breaking juicy; flavor sub-acid, rich, aromatic, spicy, something like the Jonathan ; quality good to best. Tree strong grower and very hardy. January to June. New.

Gano (S)-Originated in Missouri. Form conical, good size and smooth: deep red, shaded on sunny side to mahogany, very attractive; flesh pale yellow, fine grailled, tender, pleasant, mild sub-acid; is a good shipper and keeper; tree licalthy, rigorous and hardy. An annual and prolific bearer. February to May

Jonathan (S) - Nedium growth. R e d and yellow; tender, juicy, rich. Very productive. Onc of the best for table or market.

Grimes' Golden (S)-Medium in size; rich yellow; ranks almost with Ben Davis for productiveness, and is a much better apple in quality. Flesh yellow, solid, crisp, juicy, spicy, sub-acid; core suall. A handsome golden yellow apple; tree productive; one of the best for dessert.

lowa Blush (M) - Medium or less; finest tart flaror; tree extremely vigorous; most excellent variety. November to February.

Wolf River ( $\mathbf{N}$ ) - A new and beautiful fruit of the largest size. Skin greenish vellow, shaded with erimson; flesh white, juicy and tender. Trec a stout grower and a great bearer. Season mid-winter.

Hibernal ( $\mathbf{N}$ ) - A Russian of extreme hardiness. Fruit not extra good for dessert, but fine for cooking. Good sizc; season late fall.

Other Varieties:-Fameuse-N, I.ongfield-N, Ark. Blark-S, Mo. Pippin-S.

Crabs:- Whituey-X, Martha-N, Virginia-N, Trans(e) 


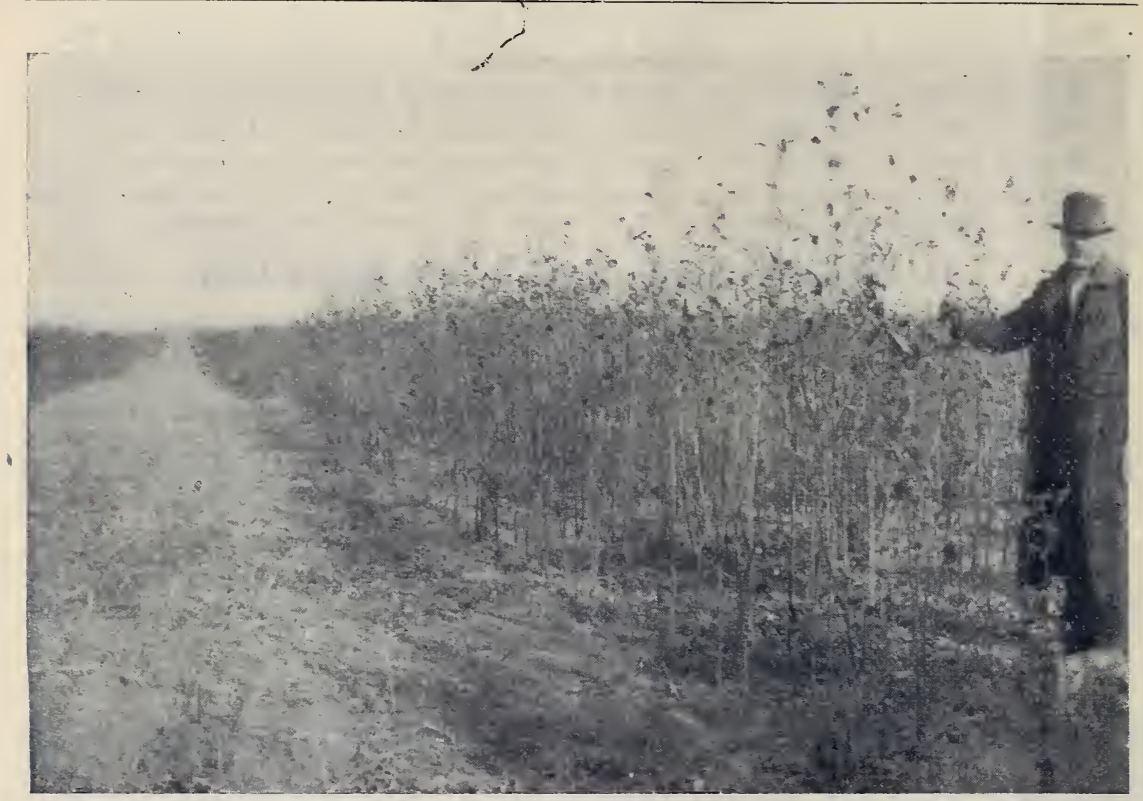

Photo. of another block of Long Scion Trees.

Prices for Special Varieties of Winter Apples, except where noted.

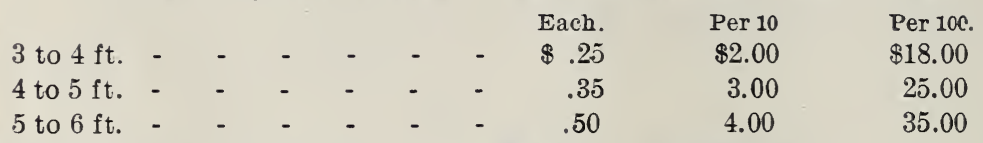

Good Pheasant (N)-Medium size; dark red: flesh tender and juicy, just tart enough for good eating. Tree an iron-clad. Russian.

Harry Kaump (N)-Medium; y ell ow: quality good; early and constant bearer. Extremely valuable for the north.

Malinda (N)-Medium to large: pea r shaped; yellow: of best quality; sweet. Tree good grower, hardy.

Special North-Western Greening $(\mathbf{N})$ - The king of apples for the north. Fruit large; round conical; color greenish yellow; flesh white and tender; tree splendid grower and hardy. Season all winter. (See colored plate on inside of cover.)

Special Wealthy $(\mathbf{N})-\mathrm{A}$ very valuable variety that succeeds everywhere, especially when grown on its own hardy roots. Bears very young. Fruit large, smooth, overspread with red: fine, juicy, vinous. Trees but four years in orchard have borne from $\frac{1}{2}$ to 2 bushels of fruit per tree.

Winter Aport (N)-Fruit large size; color greenish yellow when fully $\mathrm{ripe}$. Good quality. Tree a good grower and hardy. Scarce as yet. Each, $\$ 1.00$.

Bismarck (M)-From New Zealand. Has been fully tested in Europe and in the the United States. Said to be enormously productive, and bears very young; quality good. Tree of dwarf habit, and is largely grown in pots for decorative puposes. Not fruited with us so far. Late fall and winter. 


\section{PEARS.}

A few hardy pear trees should be in every garden as far north as Northern Iowa. Our treesare the hardiest that can be grown and will be found to give satisfaction.

4 to 6 feet Standard trees, each 50 cents; per $10 \$ 4.00$; per $100 \$ 35.00$.

4 to $5 \mathrm{ft}$. Dwarf trees, each 40 cents; per $10 \$ 3.50$; per $100 \$ 30.00$. 2 to 3 feet standard trees, each 30 cts.; per 10 $\$ 2.50$; per $100 \$ 20.00$.

Kieffer (M) - Tree a vigorous grower, an early and abundant bearer, fruit large, color rich yellow tinged with red. Flesh white, buttery and juicy. Season late fall.
Bartlett (M)-Large size fruit, with of ten a beautiful blush on sunny side; bears early and abundantly. Early fall.

Duchess ( $\boldsymbol{M})$-Very large, with rough and uneven surface; color greenish yellow, with patches of yellow and a dull red cheek; a vigorous and strong grower and a good bearer while young. Season late fall.

Additional Varieties-Wilder (M), Seckel (M) and Bessimianka (N).

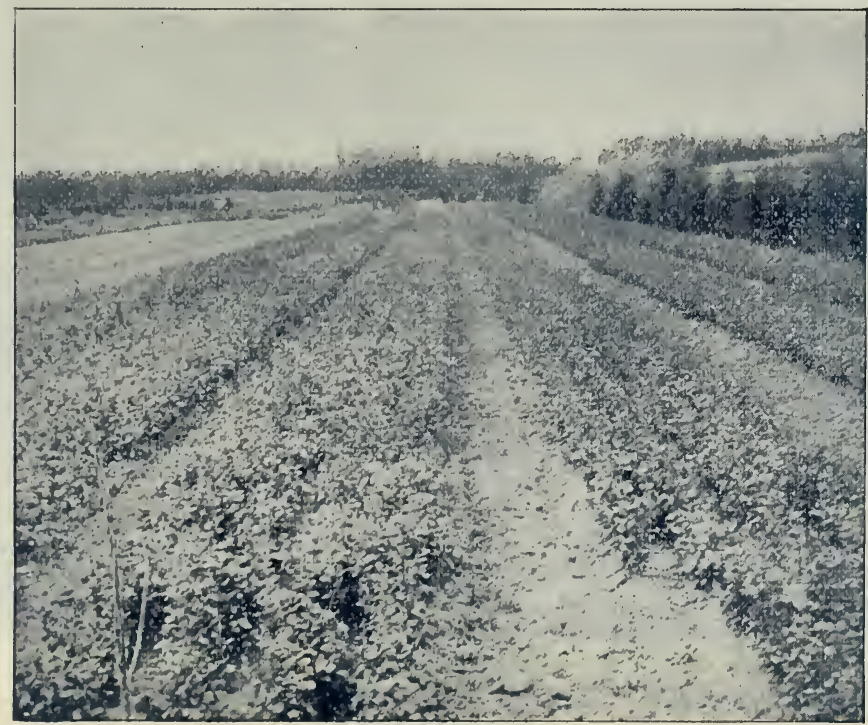

This view shows beds of Amour Berberry in the foregromnd. In the backiround are hlocks of Evergreens, A pule, Pear, Plum and C'herry.

\section{CHERRIES.}

Our stock of cherries consists of the best of the old and newer varieties.

$$
\begin{aligned}
& \text { EACH. PER 10. PER } 100 . \\
& \$ 0.40 \$ 3.75 \quad \$ 35.00
\end{aligned}
$$

Early Richmond $(\mathbf{N})-$ Too well known to need description. A profitable variety

Ostheime $(\mathbf{N})-\mathrm{A}$ very hardy cherry of Russian origin. Fruit large, roundish, obovate; flesh liver colored, tender, juicy, almost sweet, sub-acid ; very good. Season July.

English Morello ( $\mathbf{N}$ )-Large fruit; dark red color, nearly black: tender, juicy and rich. An extremely valuable variety.

Rocky Mt. Cherry (N)-A low growing dwarf cherry. Fruit medium to large, black, sweet, with a little of the wild cherry flavor. A heavy annual bearer.

Montmorency $(\mathbf{N})$-Tree hardy and an i $\mathrm{mm}$ e $\mathrm{nse}$ bearer. Commences to fruit when young and is loaded annually thereafter. Fruit large, fine flavored, and of bright shining red. 
Russian Seedlings $(\mathbf{N})-W$ e have a nice stock of Russian Seedling Cherries. They always bear nice large fruit, some sweet and others sub-acid to acid. The trees are perfectly hardy, good growers, and are valuable for experimenting where a person wishes to get a new fruit and still be sure of getting something good. Fine trees each, 75 cents.

Yellow Spanish (S)-Large; pale yellow with bright red cheek in sun; flesh firm, juicy and delicious; one of the most beautiful and popular of the light-colored cherries. Early summer.

Black Tartarian (\$)-Very large, pur plish black; flavor mild and pleasant. Tree remarkably vigorous. A general favorite.

Windsor ( $\boldsymbol{M})$-Fruit very large, livercolored and sweet. Tree hardy and prolific bearer.

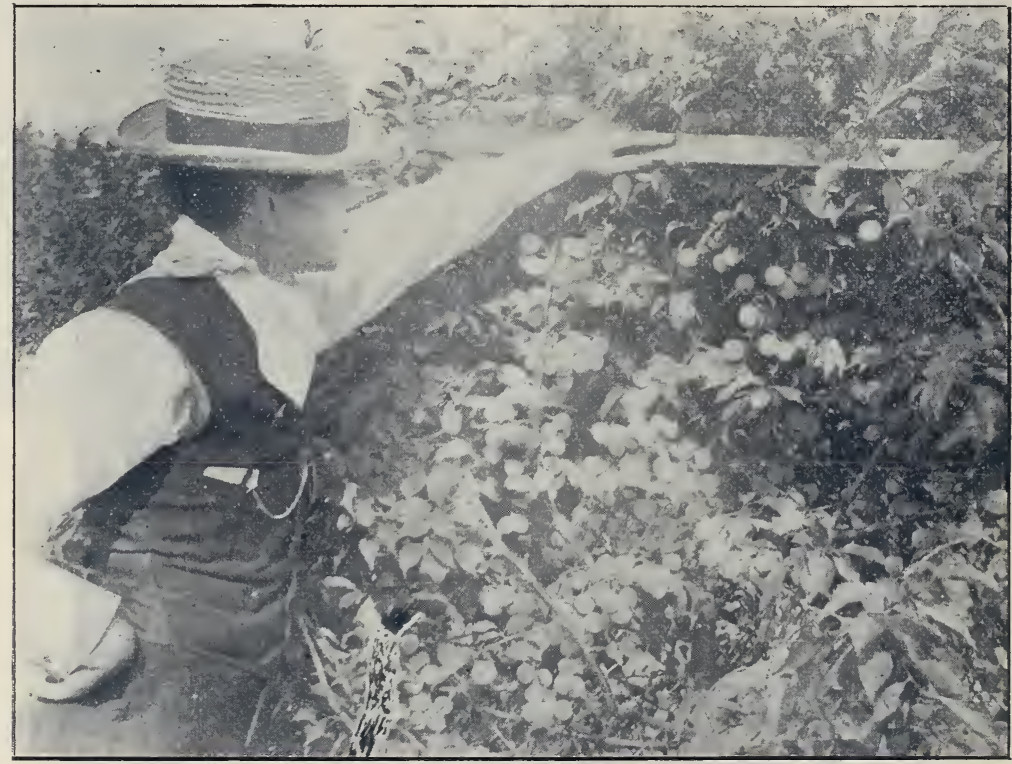

The Wyant, one of our Hardy Plum Trees the second year after planting.

\section{PLUMS.}

Our plum trees usually bear a good crop the second year after planting, and we know of no fruit that will give better returns for the money expended than will the new types of native plums. Our trees are all grown by the best propagating method, on hardy stocks which were raised from seed gathered from northern grown trees. One such tree is worth ten grown on tender stocks. Many plum trees, both in nursery and orchard, were root killed south of us in the winter of '98-' 99 - we did not lose a tree. It will pay you to buy the best.

Prices except where noted :

$$
\begin{aligned}
& 3 \text { to } 4 \text { feet, - } \quad \text { EACH. PER 10. PER } 100 \\
& 4 \text { to } 5 \text { feet, - } \quad \text { - } \quad-\quad .50 \quad 4.00 \quad 35.00 \\
& 5 \text { to } 6 \text { feet. } \quad-\quad \text { - } \quad \begin{array}{llll}
.50 & .70 & 5.00 & 40.00
\end{array}
\end{aligned}
$$

Wyant $(\mathbf{N})$-Fruit medium to large, pur- De Soto $(\mathbf{N})$-Large to very large ; purplish red. Flesh rich yellow and of ple red, with moderate bloom. best quality. One of the most pro- Flesh firm and good. Medium to ductive. Tree spreading grower, fine late. A well known and well liked foilage. A fine plum for commercial purposes. variety.

Complete directions for planting and care of nursery stock is sent with each order. Always address Gardner \& Son, Osage Nurseries, Osage, lowa. 


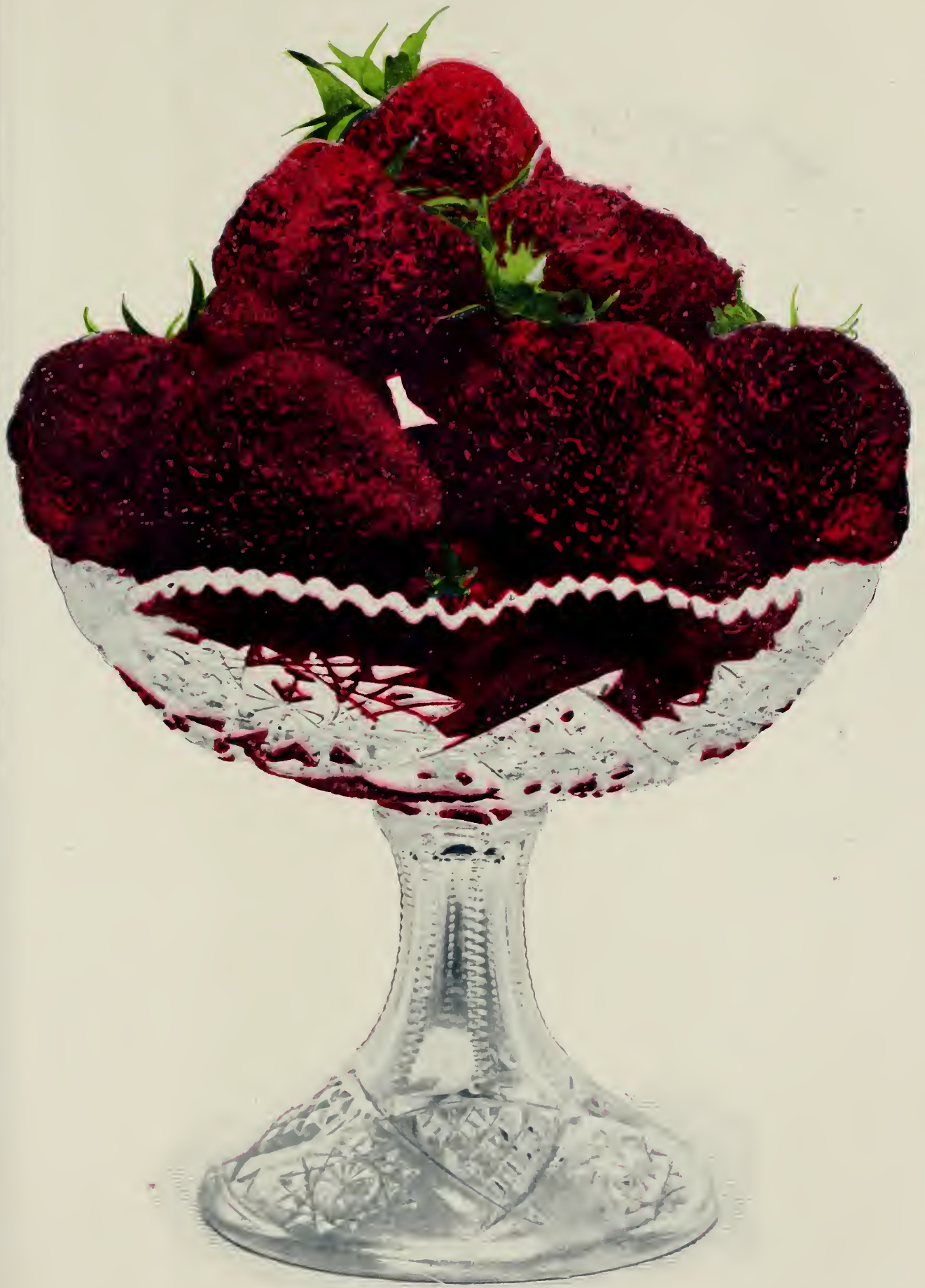

GARDNER STRAWBERRY.

The best of all for the Home Garden.

[See page 16.] 


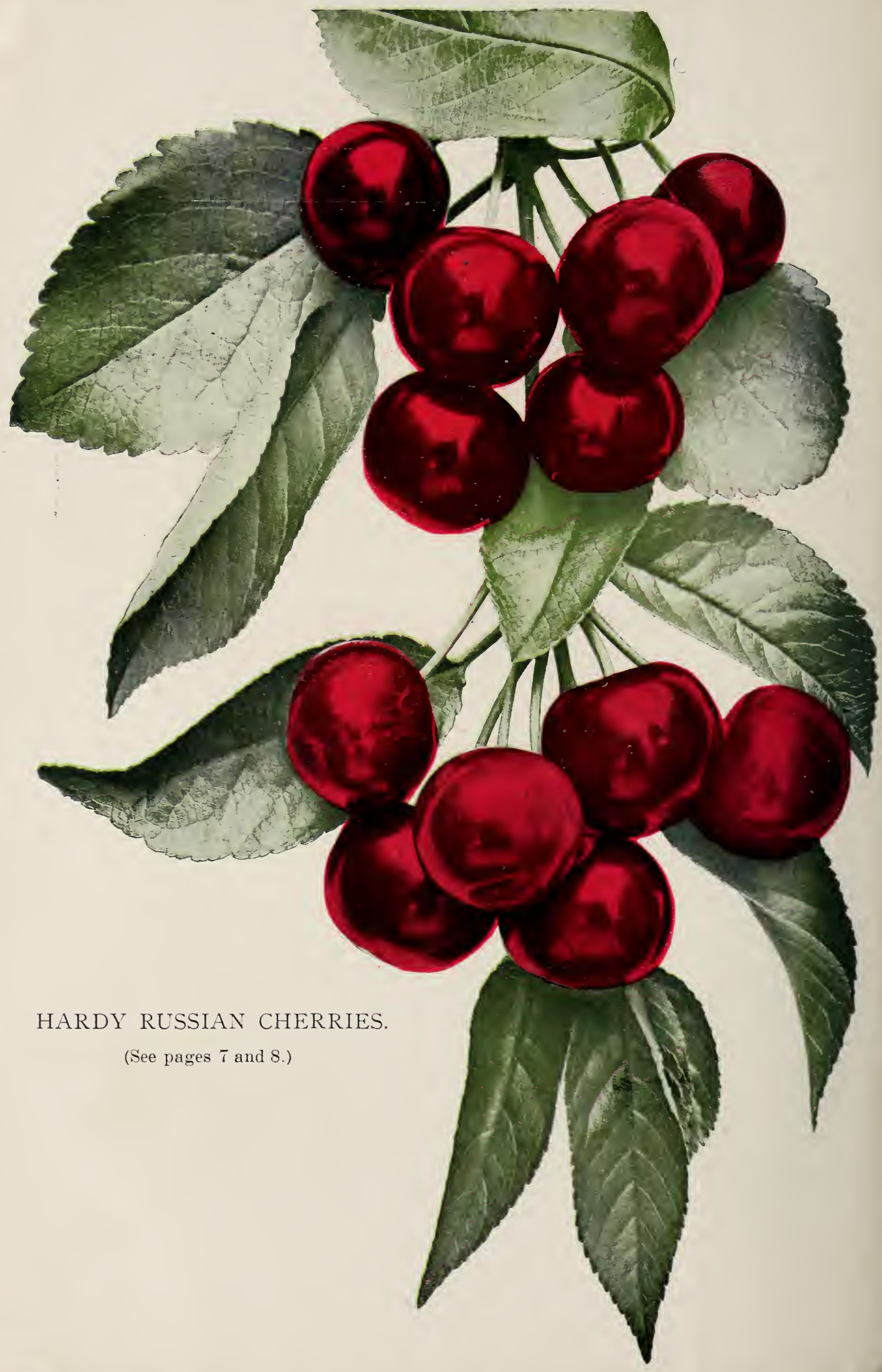


Miner $(\mathbf{N})$-Fruit large, roundish, color red. Season very late. Flesh firm and juicy, and of excellent flavor.

Charles Downing ( $\boldsymbol{M})$-A new variety and a seedling of the Wild Goose. Fruit large, red and good flavor. Tree vigorous grower and profitable. $\$ 1.00$ each. Limited.

Forest Garden $(\boldsymbol{N})$-Fruit large, nearly round: deep red with thin bloom. Tree a strong and sturdy grower. Valuable.

Wolf $(\mathbf{N})$-Fruit large, round, yellow blotched with red. Flesh firm, meaty and good. A perfect freestone. Tree a remarkable grower, and succeeds over a large scope of country.

Hawkeye ( $\mathbf{N}$ )-Fruit large to very large, round-oblong, purple red. Flesh firm and good. Clingstone. Tree good grower.

Rockford ( $\mathbf{N}$ )-Fruit medium to small, round-oblong; purple with thin bloom. Flesh rich yellow, firm and sweet, and of the best quality. Tree an annual bearer and very productive.

Additional Varieties-Lombard (S), Satsuma (S), Burbank (S), Willard (S), Abundance, $(\mathrm{S})$, etc.

\section{SPECIAL VARIETIES NEW HARDY PLUMS.}

Surprise $(\mathbf{N})-\mathrm{A}$ variety recently introduced. Perhaps the finest in quality of all the cultivated native plums. Large, deep, meaty, fine flavor. Tree thrifty, productive : season early Sept. Each \$1.50, in limited quantities. (See colored plate.)

Aitkin ( $\mathbf{N})-A$ new plum of excellent merit. Fruit very large, deep dark red; flesh firm, rich yellow, good flavor; skin thin. Tree a good grower. $\$ 1.00$ each.

Late Rolling Stone ( $\boldsymbol{N})$ - Very large, round. mottled and spotted pink purple; flesh firm, sweet and excellent. A most excellent variety for market. as it can be shipped long distances. $\$ 1.00$ each, in limited quantities.

Additional Special Varieties-Hammer $(\mathrm{N})$, Stoddard $(\mathrm{N})$, J. B. Rue $(\mathrm{N})$. Each 75 cents.

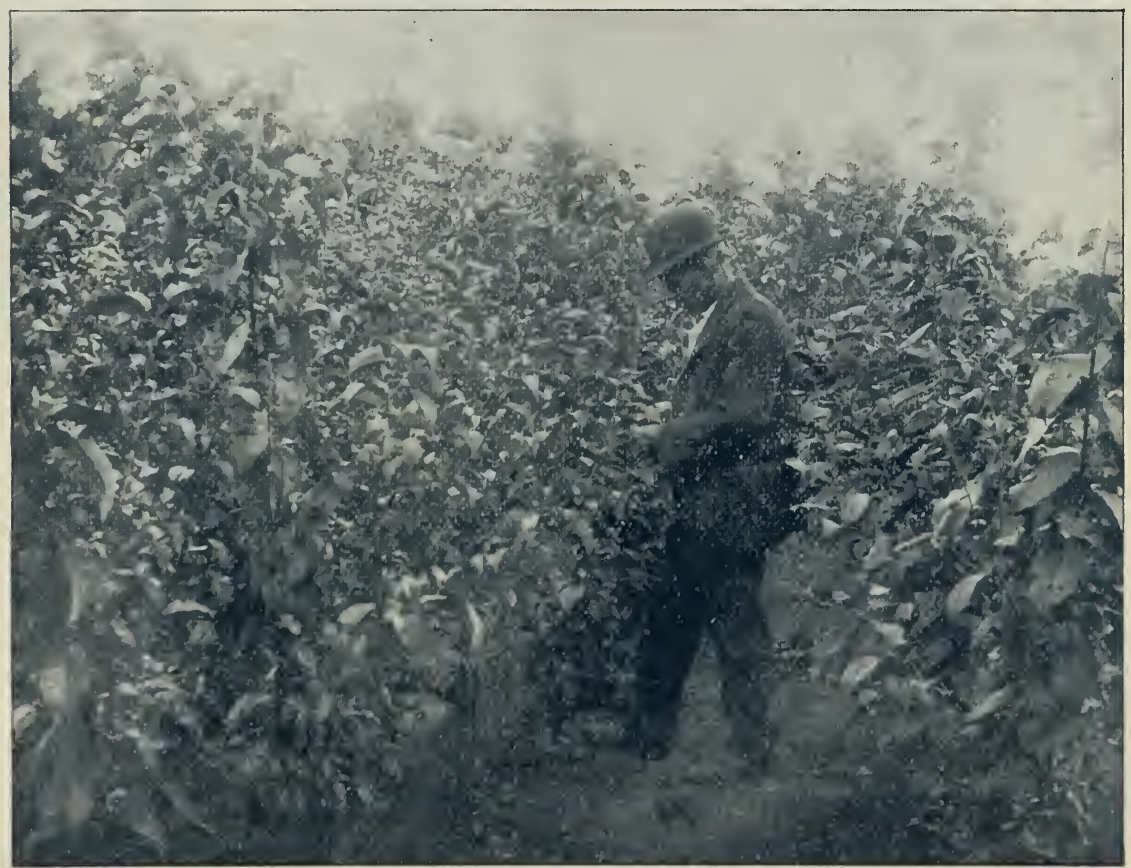

This riew shows a block of our hardy native Plum trees. Fruit as large as Apricots and of delightful flavors. Very profitable to grow for market, as fruit sells readily for $\$ 1.50$ to $\$ 3.00$ per bushel. Trees ou hardy Northern roots and are lardy in Canada. 


\section{PEACHES.}

Our peach trees are the finest that can be grown, and they will thrive and bear fruit where trees from the East and South will often fail.

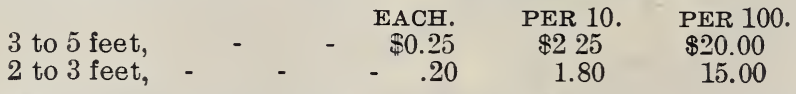

Bokara No. 3 (M)-The hardiest peach grown. Large size, fine quality and immensely productive. Each $50 \mathrm{cts}$., either size.

Elberta (S)-The great market peach. The hardiest of the southern varieties. Fruit very large, flesh yellow, very fine grain, juicy, rich anḋ splendidily flavored. A perfect freestone.

Champion (M)-Very large white freestone, with red cheek. Fine flavor. Considered frost proof.

Alexander (M)-The old standard. Too well known to need description.

Crawford's Late (M)-Fruit of large size; skin yellow or greenish yellow with dull red cheek. Tree vigorous.

Crosby (M)-Has stood 22 degrees below zero without injury to tree or fruit bud. A freestone of medium size and of beautiful color, always commanding the highest market price.

Smock Free (S)-Rather large, yellow with red cheek; very productive and valuable for market.

\section{QUINCES. (M)}

The following varieties at 35 cents each :

CHAMPION, ORANGE and REA'S MAMMOTH.

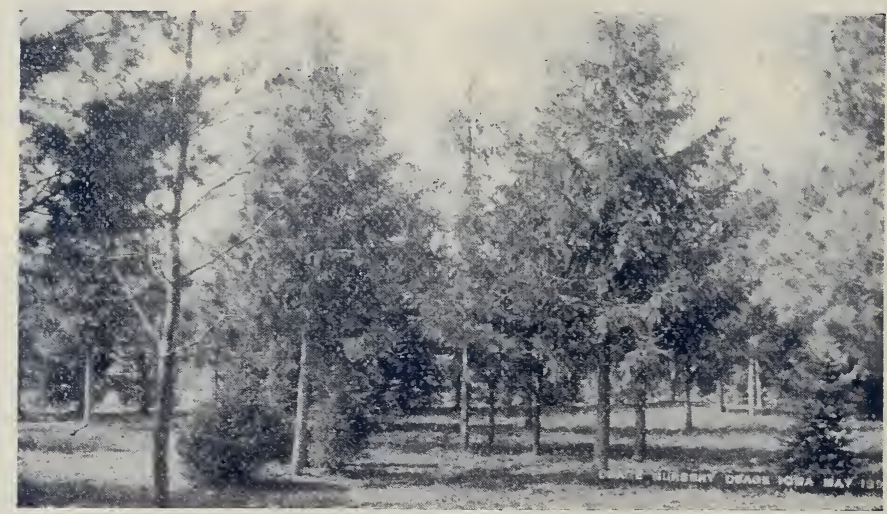

This photograph shows another view in our Nursery Park and Experimental grounds. In this view is shown different varieties of evergreens and their manner and habits of growth. The land shown here was a wild bleak prairie only 30 years ago.

\section{GRAPES.}

The grape vines we offer are extra strong ones, and will bear a good crop of fruit the second year after planting. The grape is the most healthful of fruits, and can be secured by every one who has a garden. It can be confined to a stake. bound to a trellis, trained over an arbor, and each year bear large clusters of luscious fruit.

Pruning.-Annual and careful pruning is essential to the production of good grapes. If the roots are called upon to support too much wood, they cannot bring to maturity a fine crop of fruit. The pruning should be done when the vines are dormant; usually in late fall is the best time.

Prices except where noted :

$$
\begin{aligned}
& 1 \text { year, - } \quad-\quad \begin{array}{cccc}
\text { EACH. } & \text { PER } 10 . & \text { PER } 100 \\
\$ 0.20 & \$ 1.75 & \$ 15.00
\end{array}
\end{aligned}
$$

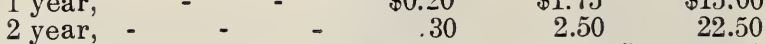

Concord (M)-Too well known to need description. Each 15c. ; per $10 \$ 1.25$; per $100 \$ 10.00$. 


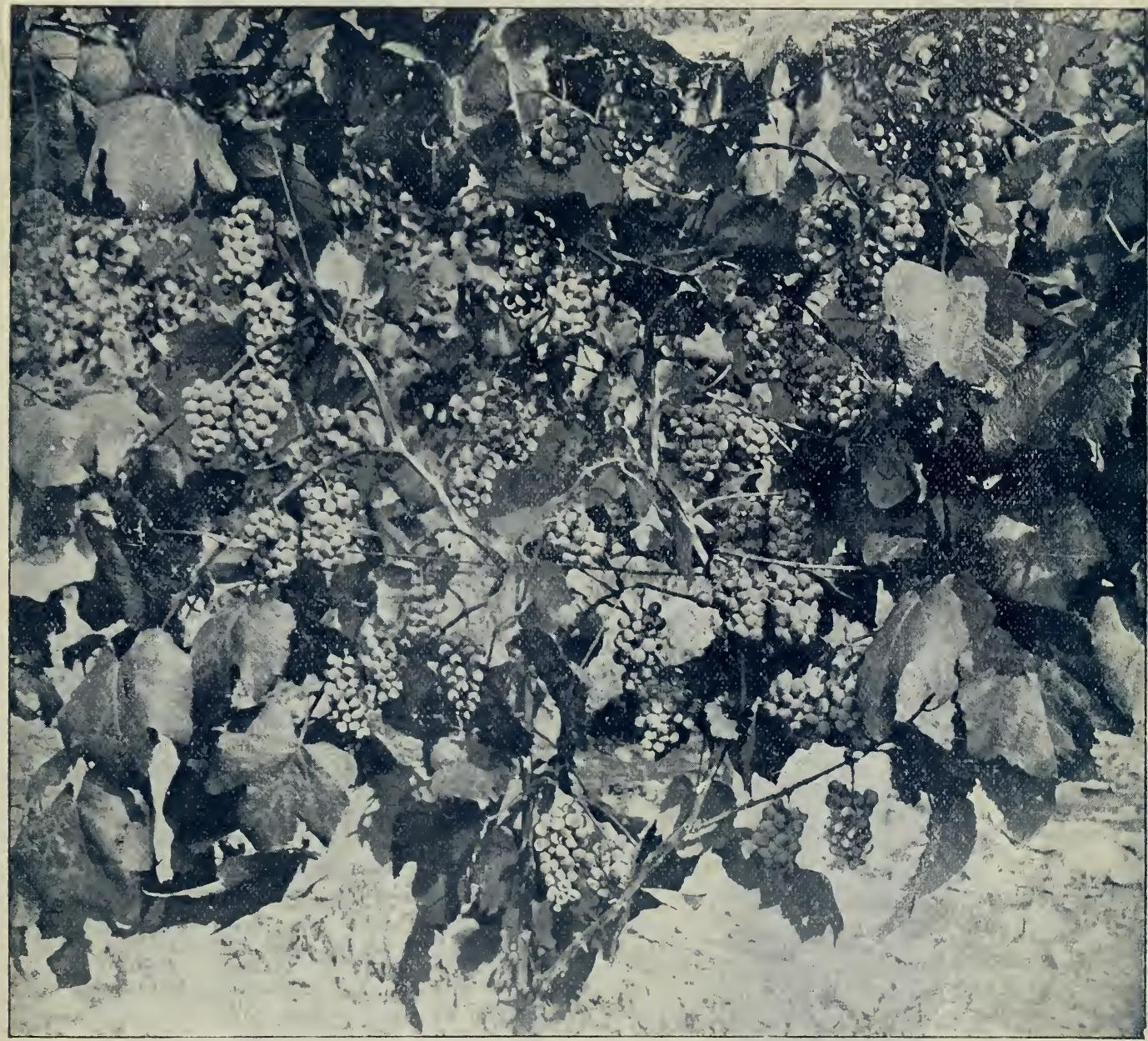

One of our Hardy Grape Vines the third year after planting in Vineyard.

Moore's Early (N)-Large, fine flavored; color black ; vine vigorous and hardy.

Worden $(\mathbf{N})$-Resembles the Concord, but ripens earlier, and fruit larger and better flavored.

Campbell's Early (N)-The earliest and best of all the black grapes. A wonderful producer of fine fruit, which sells ahead of any grape we ever raised. Vine vigorous grower; fruit black, large bunches and fine flavor. 1 year, each $\$ 1.00$, in limited quantities.
Niagara $(\mathbf{N})$-Color white, bunches large and of excellent flavor. Fine for table use; very prolific and hardy.

Moore's Diamond $(\mathbf{N})-\mathrm{A}$ vigorous grower, with dark healthy foliage, entirely free from mildew. A prolific bearer; bunches large and handsome; color greenish white; quality of the best.

Pocklington ( $\mathbf{N})$-Another good grape. Color white, with golden bloom. Vine hardy and a good grower.

Salem (N)-Color red; bunches large and compact; berry large, flesh tender and perfectly free from hard pulp. 
Agawam ( $\mathbf{N})$-Color dark red or maroon ; bunches large; berries large, flesh tender and juicy.

Wyoming Red ( $N$ ) - An extra early grape of great value. Bunch compact and handsome; size double that of the
Delaware. Season very early. The best market grape of the red varieties. Each 75 cts. ; $\$ 5.00$ per 10 .

Other Varieties-BRIGHTON-N, DELAWARE-N, MARTHA-N, EARLY OHIO-N, etc., etc.

\section{SELECTED $\square$ CURRANTS.}

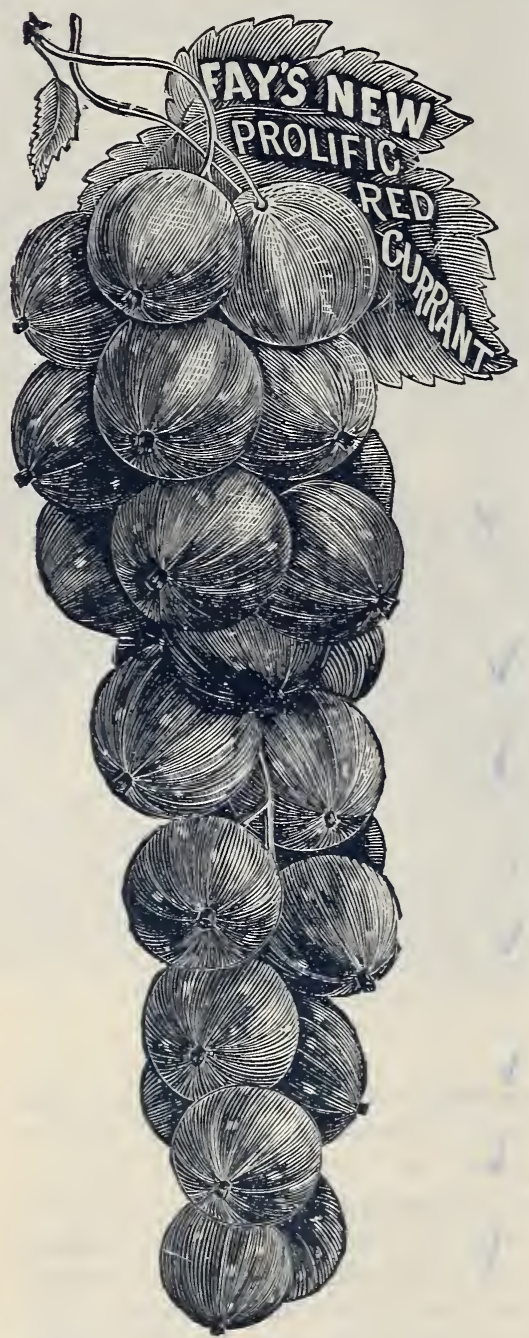

A practical fruit grower says : "I make more from my two acres of currants year in and year out, than from any other two acres on my fruit farm." Ripening just before the raspberries, and continuing in prime order for several weeks, easy to ship and always bringing a good price, there is nothing more easily and more satisfactorily handled than the currant. Plant in rows 4 feet apart each way. Keep free from weeds and in a good state of fertility. Prune freely every spring. For worms use White Hellebore applied with our "AUTOMATIC SPRAYER."

Prices except where noted :

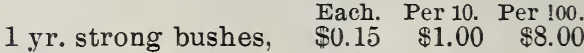

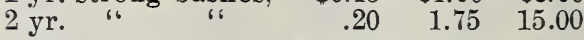

Victoria (N) Red-A splendid variety, ripening later than most others and hanging on bushes for a long period in the best of condition. Bunches long, and berries of good size.

North Star $(\mathbf{N})-A$ thrifty grower. Color fruit red; bunches large. One of the best.

Red Dutch (N)-An old, well-known variety. Medium size, good quality and very productive.

Fay's Prolific $(\mathbf{N})-$ Berry and bunch very large and of fine flavor. Bush a strong grower. Red.

Pomona (N)-A new currant. More prolific and fruit with fewer seeds and of better flavor than the common sorts. Color a beautiful clear bright red. Each 25 cents.

Black Champion $(\mathbf{N})$-The finest of the black currants. Berry very large size and of excellent fiavor.

Lee's Prolific $(\mathbf{N})$-Another good black variety.

White Grape $(\mathbf{N})$-Berry large size, color white, sweet or mild acid, excellent quality and valuable for table use. Very productive.

White Dutch $(\mathbf{N})$-Too well known to need description.

TREE CURRANT $(\mathbf{N})$ - We can furnish Red, White and Black varieties grown in tree form. They make sturdy little trees and bear heavily, keeping the fruit up from the ground away from the chickens, etc., etc. Nothing can be prettier than a well kept row of tree currants. Prices 2 to 3 feet, 50 cents each.

Remember we make no charge for boxing. ALL stock is F. O. B. cars here. Address. Gardner \& Son, Osage Nurseries, Osage, lowa. 


\section{GOOSEBERRIES.}

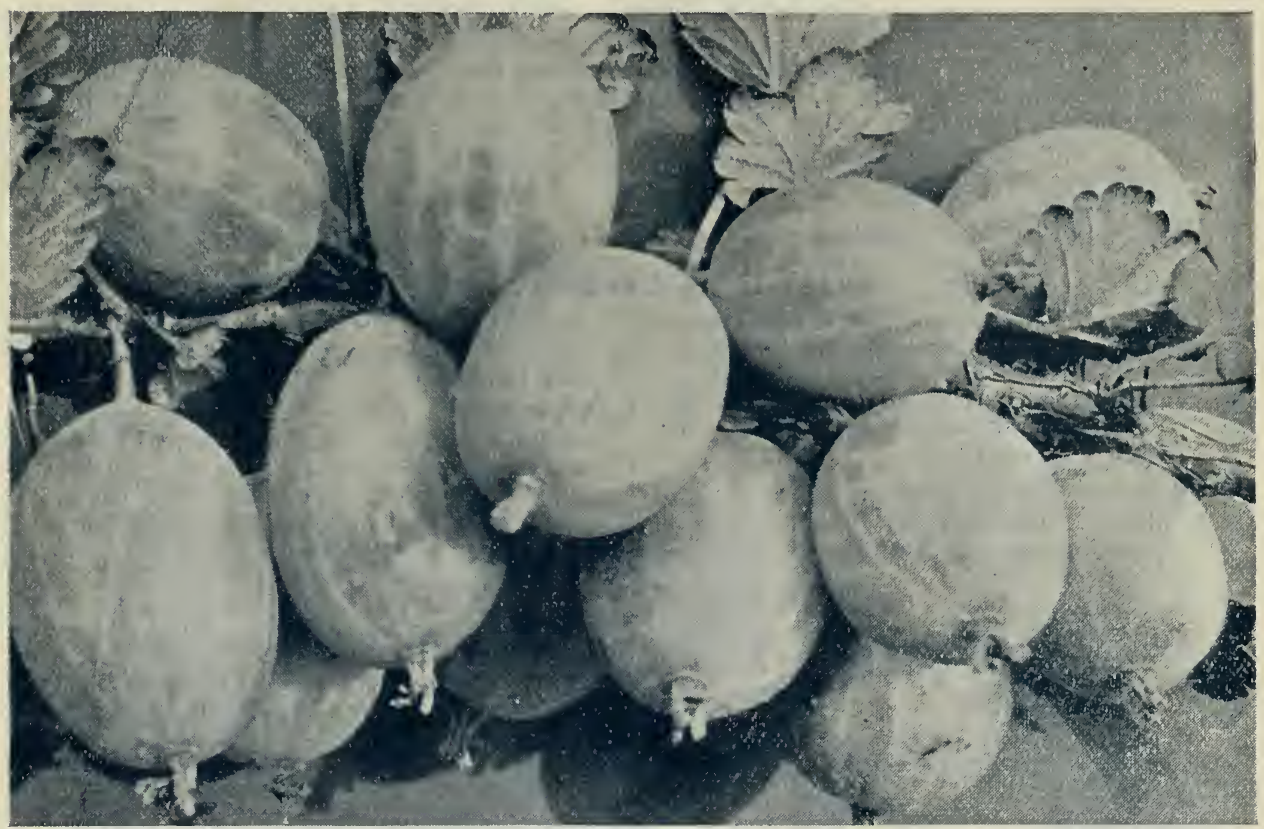

This photo shows the Downing life size. For all-round purposes this variety is hard to beat.

The Gooseberry is being cultivated more and more extensively as its great value for home and market use is becoming known. This fruit may be shipped long distances by freight and arrive at market in the best of condition, always bringing a good price. Our plants are of extra fine quality, and our varieties are the ones which experience has proven to be the best.

Prices except where noted:

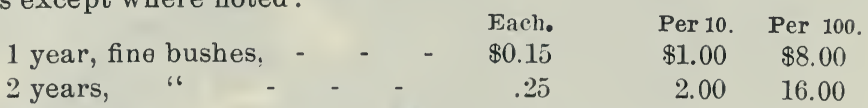

Downing ( $\mathbf{N})$-Large size fruit, oval, greenish white. Plant very vigorous and hardy. Bears abundantly and is a popular favorite.

Houghton's Seedling ( $\mathbf{N}$-_-Fruit medium to large, color when ripe pale red; tender, sweet and of excellent flavor. Bush a strong grower.

Smith's Improved $(\mathbf{N})$-One of the largest of the American varieties. Color when ripe a light green; sweet and excellent; plant vigorous and hardy.

Pearl ( $\mathbf{N})$-A new variety, originated in Canada. A wonderful cropper, strong grower. Each 50 cts.: $\$ 4.10$ per 10 .

Industry ( $\mathbf{N})$ - An English variety of the largest size; color dark red; rich and agreeable. Plant remarkable for strong growth and the immense amount of fruit it carries. Each 0 cts.; $\$ 4.00$ per 10 .

We can furnish above varieties of gooseberries grown in tree form at $50 \mathrm{cts}$. each.

ORDER EARLY.-A great deal is gained by sending in your order early. We can do better by early orders than by those that come in right in the rush of digging and packing time. Look this catalogue over and order what you want AT ONCE while you feel like it. Always address, Gardner \& Son, Osage Nurseries, Osage, lowa. 


\section{SELECT RASPBERRIES.}

Coming immediately after strawberries, when there is a dearth of other fresh fruit, raspberries are much sought after for planting in the garden and also in the field for market. They are easily cultivated, and beds seldom require renewing. Their season of ripening is long and fruit always in demand. Plant in good soil and manure from time to time freely. Plant four feet apart each way. Cut out the old shoots each spring.

Prices except where noted :

$\begin{array}{lcccr} & \text { Each. } & \text { Per 10. } & \text { Per 100. } & \text { Per } 1000 . \\ \text { Strong well rooted plants, - }-~ & \$ .15 & \$ 1.00 & \$ 5.00 & \$ 30.00\end{array}$

\section{RED VARIETIES.}

Turner $(\mathbf{N})$-Fruit good size, light handsome red and of fine flavor. Hardy.

Cuthbert (N)-Fruit large, deep rich crimson, firm and of the best. Hardy and productive.

Miller ( $\mathbf{N})$-Eruit large, red and of fine flavor. Bush a stout, healthy grower, holding up the immense crops of fruit. Early in ripening and a good shipper. Each 20 cts.; per 10, $\$ 1.50$; per $100, \$ 6.00$.

Kenyon ( $\mathbf{N})$ - A new variety that beats them all in size and quality. Fruit very large, color dark purple. Bush hardy and a heavy bearer. The best shipper we have. Each 20 cts.; per $10, \$ 1.50$; per $100, \$ 6.00$.

\section{BLACK VARIETIES.}

Kansas (N)-Color jet black, firm and / fine quality. All should plant it. delicious; large size. The hardiest blackcap known.

Gregg (N)-Fruit large size, color black,

$\operatorname{Older}(\mathbf{N})-$ One of the hardiest varieties. Fruit large, color black and good quality.

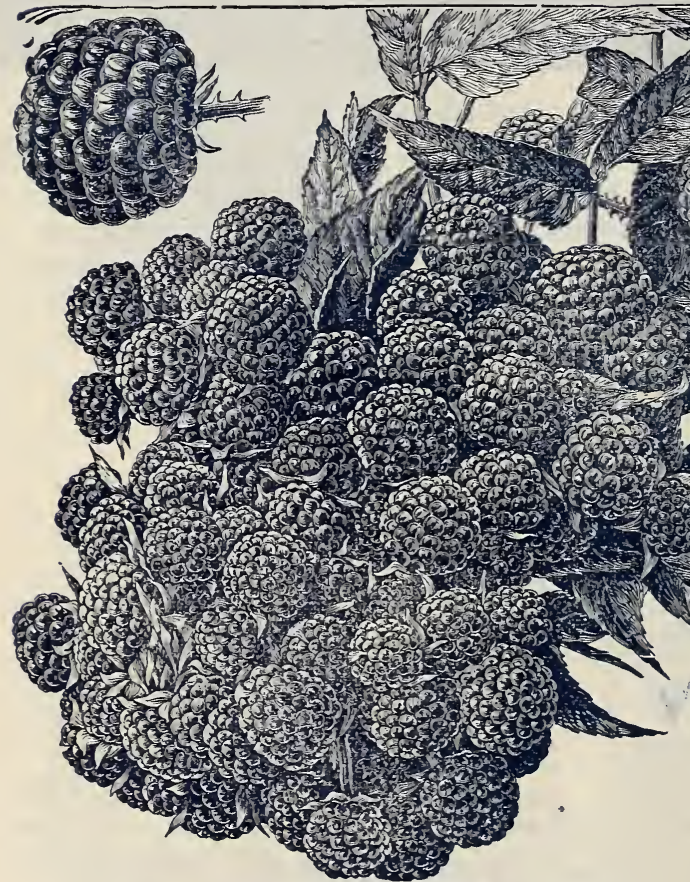

THE GAUL'T EVERBEARING RASPBERRY.

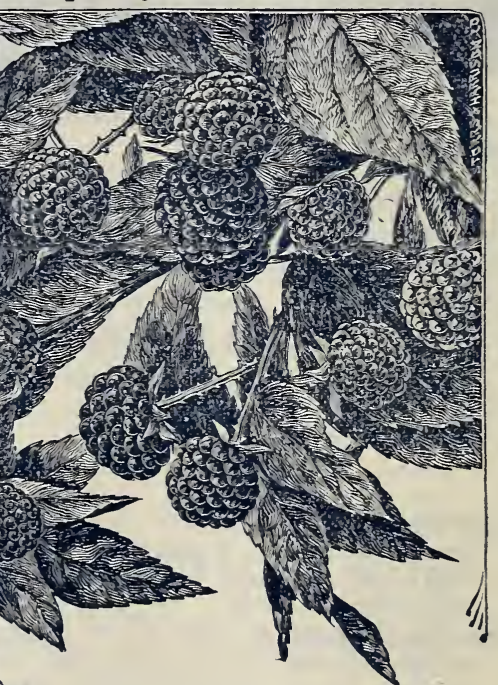

Gault Everbearing ( $\mathbf{N})$-The only true perpetual raspberry we know of. It bears a full crop of fruit at the usual time and then continues to bear large clusters of fruit on new growth until checked by frosts. We have counted over ninety berries on a single cluster. Very valuable and sure to be appreciated as it becomes better known. Each 50 cts.; per $10, \$ 4.00$; per $100, \$ 30.00$.

If you wish to get a few orders from your neighbors, write to us for terms. Address, Gardner \& Son, Osage Nurseries, Osage, lowa. 


\section{YELLOW VARIETIES.}

Golden Queen (N)-Rich golden color; fruit large size and of the most exquisite flavor. Very hardy and will succeed well in the north.

\section{BLACKBERRIES.}

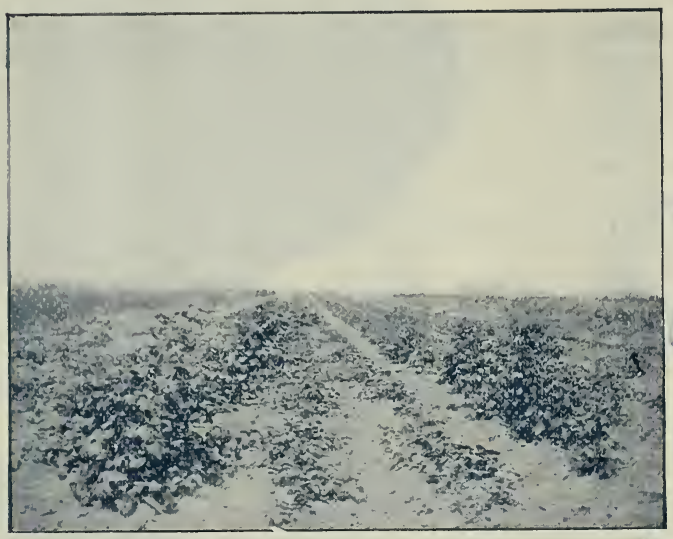

A glimpse of one of our Small Fruit Plantations.

This excellent and profitable fruit is ('asily grown, and is a sure cropler each year, bringing in large returns as the fruit always brings a good price. Plants should be set in rows five feet apart, with plants threo feet in the row Give same care as required for raspberries.

Strong plants, eacli 15 cts.; per 10 , $\$ 1.00$; wer $100, \$ 5.00$.

\section{VARIETIES.}

Snyder $(\mathbf{N})$ - The old standby for the extreme nortli. Very hardy ; fruit of the largest size, with no hard core and of the: finest flavor.

Ancient Briton $(\mathbf{N})$ - Another hardy variety of exeellent merit. Fruit good size without hard eore. Ripens a little later than the Snyder.

Lucretia ( $\mathbf{M}$ ) Dewberry-A trailing form of the blackberry. Fruit of the largest size. Does not snceeed over as large a seope of comntry as the upright form.

\section{STRA WBERRIES (all N).}

We now grow all our strawberry plants fin propagating beds, carefully removing all r fruit stems as they appear and not allowing the plants to bear any fruit, thus tlurowing all the strength and vigor that nsually go into tle fruit, into the plant. One plant grown in this way is worth 20 dug from fruitiug bed where the vitality lias been allowed to wo into the fruit. True, the plants cost more, but they are worth it, because they grow vigourously, making many plants. whieh bring forth a harrest of large, luseions fruit. that is a delight to the grower. Partios who grow berries for the market can afford to sell the CHEAP plants as they get their money from the fruit, and would plow the plauts up anyway. So whatever they ean get for them, 75 ets. to $\$ 1.50$ per 100, they are aliead. Buy the best and do not be disappoin ted when fruiting time comes.

Varieties marked $P$ (Pistillate) must liave varieties marked S (Stamiuate) set witl them to insure fertilization and full crou of fruit. Staminate varieties will bear aloue but pistillate varieties must have staminates set with them. Strong Pedigree plants, except where noted:

$$
\begin{array}{cccc}
\text { Eaeh } & \text { Per } 10 & \text { Per } 100 . & \text { Per } 1000 . \\
\$ .05 & \$ .40 & \$ 2.50 & \$ 12.00
\end{array}
$$

Haverland-Exceedingly vigorous : imperfect flower; heavy bearer of fine large berries of pale scarlet color. A general favorite. (P)

Warfield-Imperfect blossom. One of the free-growing plant makers. Very productive. In size and form of fruit it closely resembles the old Wilson. (P)

Crescent-Medium, uniform, conical, bright scarlet; plant a wonderful grower. Succeeds everywhere. (P)

Bederwood-A perfect flowering variety of great excellence. A heavy cropper of fine large fruit. (S)

Lovett-Plants are perfect beauties, perfectly healthy, no rust; sends out plants profusely; if allowed, it will cover the entire row with fine plants. One of the best for main crop to fertilize Haverland and other good pistillate sorts. (S)

Enhance-Berries as large as Sharpless, and very productive. Perfect blossoms; plant a very strong, healthy grower. This variety stands high with the growers all over the country and is one of the standards. (S)

Michel's Early-One of the earliest if not the earliest variety grown. It does better on light, warm soil; on heavy soil it goes too much to vines. It is one of the best varieties to fertilize with, as it blossoms early and late. For best results plant on warm, sandy soil. Valuable on account of its earliness. (S) 
Gardner-A new variety found growing wild on our grounds. Plant srong grower, averaging from 16 to 18 inches in height. Fruit large to very large, roundish conical, bright crimson and excellent in quality, having the delicious flavor of the wild strawberry. A wonderful fertilizer, producing more pollen than any other variety we know of. A good plant maker and succeeds on all soils. Each 15 cents; per 10, $\$ 1.00$; per 100 , $\$ 6.00$. This variety has received many very flattering announcements from prominent Horticulturists. It is sure to please you. (S)

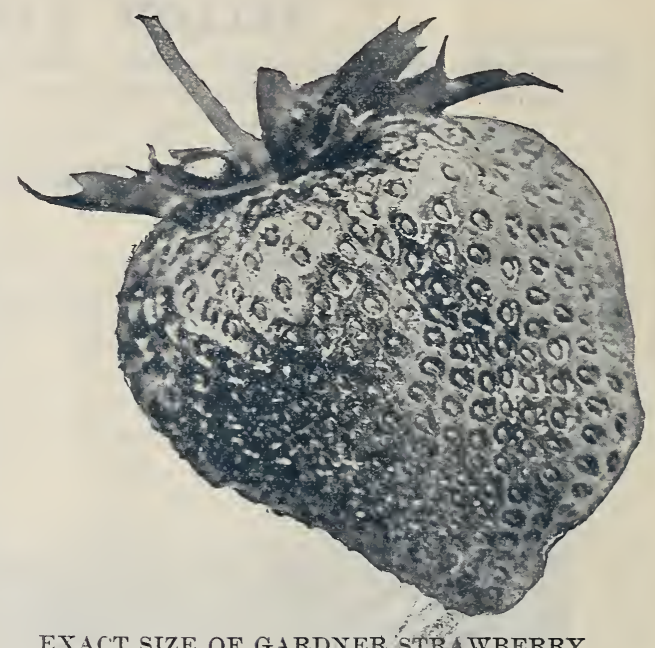

EXACT SIZE OF GARDNER STRATBERRY.

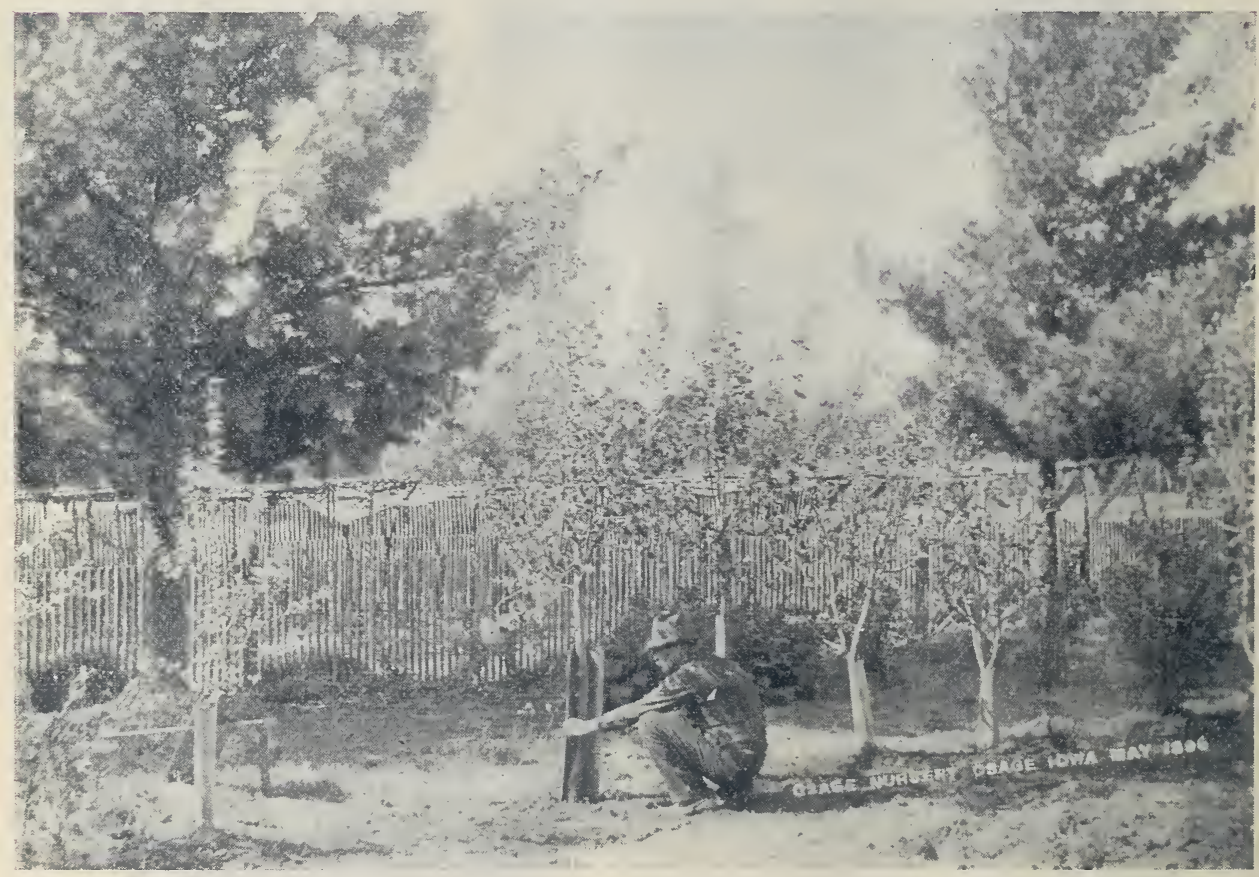

Another view in our Nursery Park and Experimental Grounds. In the foregound our Mr. C. F. Gardner is putting tree protectors around some Experimental Pear and Apple trees. In the background may be seen the lath shade, under which we grow millions of Evergreens from seed.

A certificate of Nursery inspection, certifying that our nurseries have been examined and found to be free from all insect pests, is attached to every order that leaves our nurseries.

Do you want to make more money from 5 acres of land than you have made from your whole farm in growing general farm produce? If so, plant $s$ mall fruits for the market. Always address, Gardner \& Son, Osage Nurseries, Osage, Iowa. 


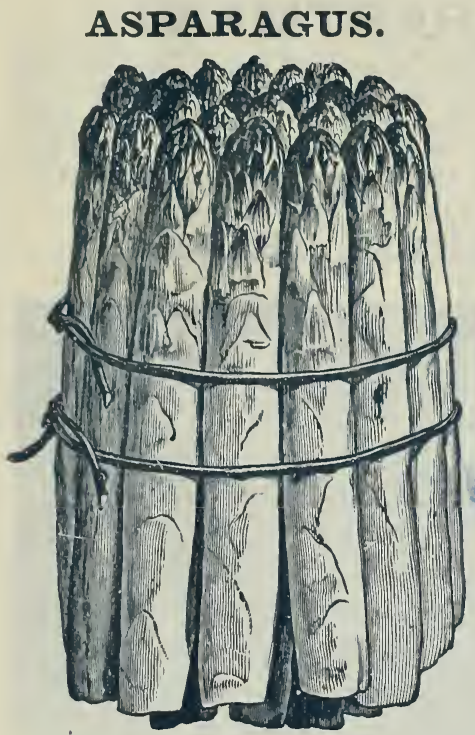

This is the earliest and the finest of the spring vegetables. It is very profitable to grow both for home use and market, as a bed once established will remain in good condition for 30 years or more. Have ground in good condition and place plants 8 inches apart in the row with rows 3 feet apart. Plant deep enough so that the crowns are covered with from two to three inches of mellow earth. Give liberal dressing of manure from time to time and $3 \mathrm{lbs}$. of salt to the square yard each spring. Do not cut for use until the second season. Does anyone near you grow asparagus for the home market? If not, why don't you? There is BIG MONEY made in supplying the home market with this easily grown vegetable.

Conover's Colossal $(\mathbf{N})-$ Much superior in size and quality to the old varieties. Remarkably tender and fine flavored.

Palmetto (N)-This new variety has been thoroughly tested both in the north and south, and is found to be the best early variety grown. Fit to cut before the Conover. Price on above varieties, each 15 cents; per $10, \$ 1.00$; per $100, \$ 6.00$.

\section{RHUBARB (Pie Plant).}

This deserves to be ranked among the best early products of the garden. It affords the earliest material for pies and fresh table sauce, and continues long in use. Ground should be rich and deep. Plant four feet apart each way.

Myatt's Linnæus (N)-This is a variety of superior quality. Early and very tender, having a mild sub-acid flavor.

Early Scarlet (N)-Smaller than Myatt's, but extremely early and of high quality. Prices, either variety, 25 cents each, $\$ 2.00$ per 10 .

Improved Dwarf Juneberry (N)-A valuable fruit resembling the Huckleberry, and most excellent for pies or canning. Hardy. Each 25 cents, $\$ 2.00$ per 10 .

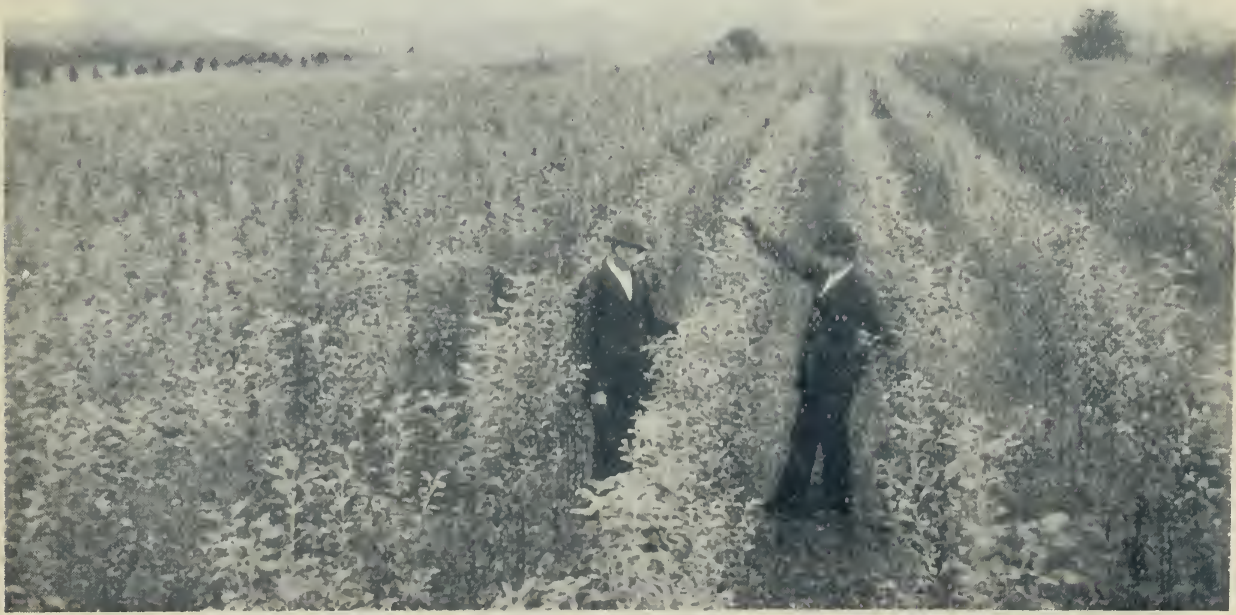

This photo, shows another block of "Long Scion" A pple trees 2 years old. 


\section{ORNAMENTAL DEPARTMENT.}

In no other way can the home grounds be made so beautiful and attractive as by the judicious planting of ornamental trees, shrubs and plants; and a few trees and flowering shrubs will greatly add to the selling value of a place which may otherwise be undesirable. We aim to grow a complete line of the choicest and best ornamental stock and have many different trees, shrubs, plants and vines not listed here. Write for prices on any stock not found herein.

\section{SHADE AND ORNAMENTAL TREES.}

Am. Mt. Ash (N) - A favorite, erect growing tree of medium size, producing white flowers in the early spring, followed by clusters of bright scarlet berries which remain on the trees during the winter months. Each, 5 to $6 \mathrm{ft}$., 50 cts. 4 to 5 ft., 30 cts. 3 to $4 \mathrm{ft} ., 20$ cts

Weeping Mt. Ash (N)-One of the finest of the weeping trees, suitable for the lawn and cemetery planting. Each \$1.50.

Poplar Leaved White Birch (N) -A fast growing shade tree. Very desirable for street planting. Makes elegant shade. $\mathrm{Each}$ $\$ 1.50,6$ to 8 feet.

C. L. Weeping Birch (N)-One of the most desirable and beautiful trees for dooryards, having white or silver bark and branches of a graceful drooping habit. It is perfectly hardy and a rapid grower. Each $\$ 1.50,5$ to $7 \mathrm{ft}$.

Horse Chestnut $(\mathrm{N})-\mathrm{A}$ beautiful, well-known tree, forming a compact round head, with dark green foliage and an abundance of showy flowers early in the spring, and ripening large clusters of nuts

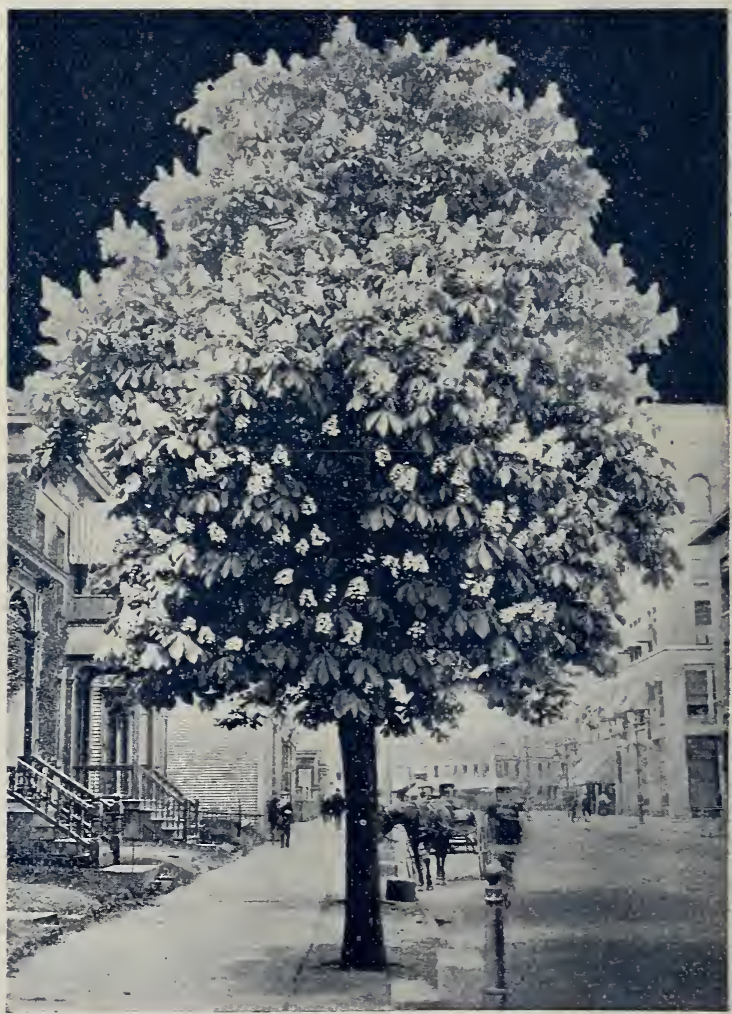

Photo. of Horse Chestnut, in use as Street Tree. early in the fall. Very hardy, 5 to 7 ft., $\$ 1.50$ each; 4 to $5 \mathrm{ft}$., $\$ 1.00$ each; 1 year, 25 cents.

Red EIm (N)-One of the fastest growers of the Elms, and makes a quick and handsome shade tree. 5 to 7 feet, 50 cents each.

Weir's Cut-Leaved Maple (N) - Very attractive, and much planted in the east. Hardy and well suited for the northwest. 6 to 8 feet, $\$ 1.50$ each:

Silver Maple $(\mathbf{N})-\mathrm{A}$ fast growing shade tree of extreme hardiness. 5 to 10 feet, 75 cents each.

Hard Maple (N)-A slow grower, but

much used for street purposes. $\Sigma$ to 7 feet, 50 cents each.

White Ash (N) - A fine shade tree; fast grower and of extreme hardiness. 5 to 7 feet, 50 cents each.

Mulberry, (Teas' Weeping Russian)-A weeping variety of the Russian Mulberry. Perfectly hardy in summer and winter; withstands extreme heat and cold, and grows naturally in a very graceful form. $\$ 1.50$ each.

Weeping Willow $(M)-A$ fine weeping tree for cemetery, lawn or any place where a low-growing tree is desired. Each $\$ 1 . \tilde{0} 0$.

Remember that first-class stock always commands first-class prices. Do not be deluded into the thought that someone is going to furnish first-class stock at second-class prices. In buying anything it always pays to buy the best and this is specially true when it comes to Nursery stock, 
Japan Catalpa ( $\mathbf{N})-\mathbf{A}$ beautiful, rapid growing tree, very suitable for Lawn, Park or Street planting. As hardy as an oak. Flowers freely. 4 to 6 feet. 75 cents each.
Russian Olive ( $\mathbf{N})$-An extremely hardy ornamental tree. Beautiful silvery foliage; blossoms freely early in spring; very fragrant. 3 to 4 feet. 75 cents each.

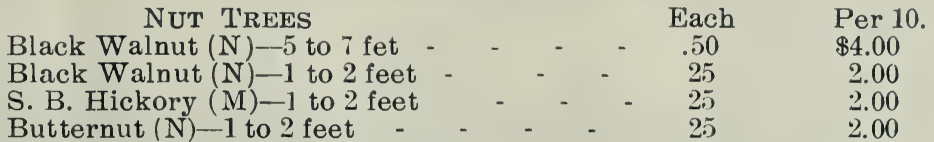

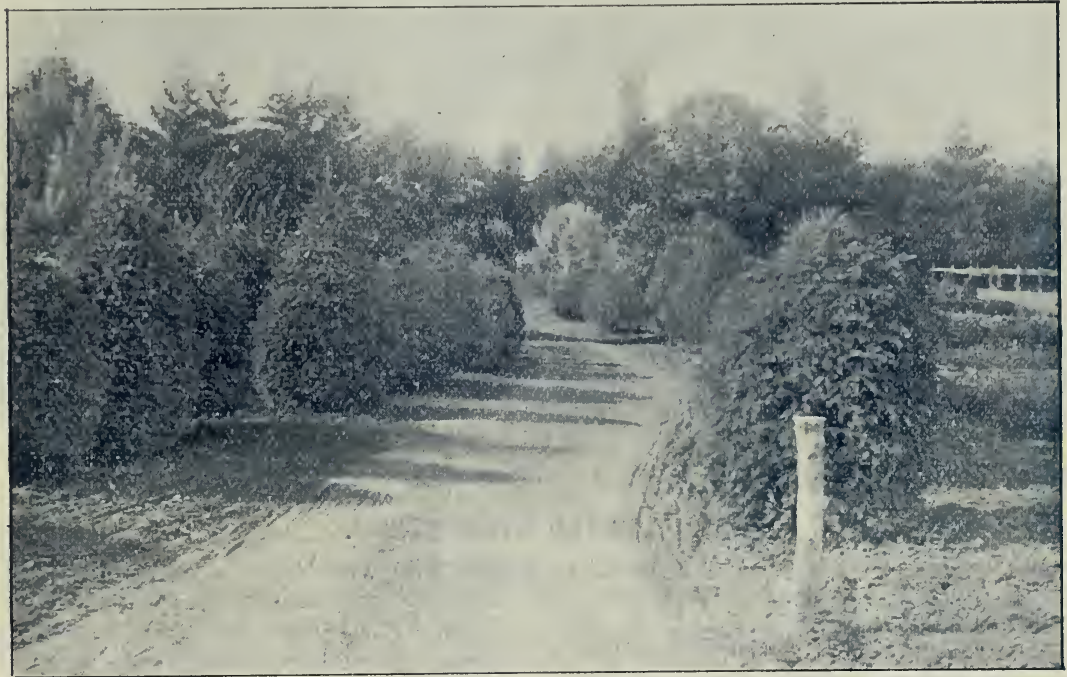

A Driveway in our Nursery Park. The silvery tree in the distance to the right of road is a specimen of Russian Olive.

\section{EVERGREENS.}

We only grow Evergreens of the hardiest varieties, but we grow those in large quantities. We have no wild or imported evergreens to offer at any price, as we grow all of our trees from seed, here in our nurseries. Nursery grown trees are worth from $50 \%$ to $500 \%$ more than wild trees, which are often worse than worthless. After thirty years' experience in growing and shipping evergreens, we feel that we are in a position to fill your wants as well, or a little better, than any other nursery. No matter how far you live from us, we pack so that stock will reach you in good growing condition.

Special Hints in Regard to Planting Evergreens.-The proper time to plant Evergreens is either in September or in April and May. They do not do well if planted late in the fall. DO NOT PLANT TOO LARGE TREES, especially if they are to be shipped any distance. 12 to 18 inches in a good transplanted grade is the best size for shipping for wind-break purposes. Use extra care not to expose roots to the air for an instant. Pack earth firmly about the roots, using water whileplanting if ground is dry. After planting keep ground loose around the top by frequent cultivation, or mulch heavily as soon as planted, which ever you prefer to do. 


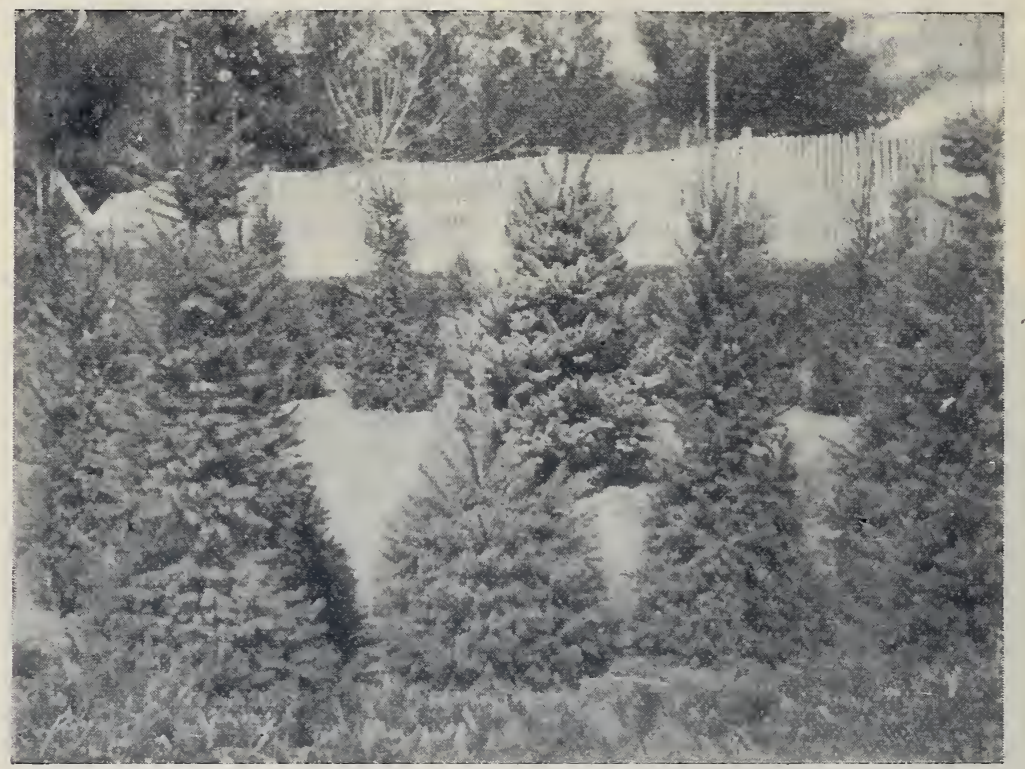

This Photo-plate shows a Group of Faney Transplanted Evergreens in our Nursery Park.

\section{TRANSPLANTED EVERGREENS.}

Norway Spruce $(\mathbf{N})-A$ general favorite. Too well known to need description; will succeed everywhere. 18 to 24 inches 25 cents each: $\$ 20.00$ per 100 . 12 to 18 inches 15 cents each; $\$ 11.00$ per 100 .

Arbor Vitæ (N)-The favorite hedge tree. A fast growing evergreen, and will stand pruning with impunity. 12 to 18 inches 15 cents each : $\$ 15.00$ per 100. 8 to 12 inches 11 cents each: $\$ 9.00$ per 100 .

White Pine $(\mathbf{N})$ - A fine wind-break tree. Perfectly hardy and a fast grower. 2 to $2 \frac{1}{2}$ feet 35 cents each; $\$ 30.00$ per 100. 18 to 24 inches 20 cents each : $\$ 20.00$ per 100 . 12 to 18 inches $20 \mathrm{cts}$. each ; $\$ 18.00$ per 100 .

Ponderosa Pine $(\mathbf{N})$ - This noble tree attains the height of 100 feet, and is perfectly hardy. It is a rapid grower, with needles from 6 to 10 inches in to 18 inches 30 cents each; $\$ 20.00$ per $100 ; 18$ to 24 inches 50 cents each. length, of a silvery green color. 12

Scotch Pine $(\mathbf{N})$ - This variety is probably more extensivly planted than any other of the pines. A good tree. 2 to $2 \frac{1}{2}$ feet 30 cents each ; $\$ 25.00$ per 100. 18 to 24 inches, 25 cents each; $\$ 20.00$ per 100 . 12 to 18 inches, 18 cts. each; $\$ 15.00$ per 100.

Austrian Pine ( $\mathbf{N})$-Resembles the Scotch Pine, but has longer and heavier needles. A fast growing tree, much planted. 18 to 24 inches, $25 \mathrm{cts}$. each; $\$ 20.00$ per 100 . 12 to 18 inches $20 \mathrm{cts}$. each ; $\$ 15.00$ per 100 .

Balsam Fir ( $\boldsymbol{N})-$ An upright growing tree of beautiful appearance. Leaves dark green above and silvery beneath. A rapid grower. 12 to 18 inches, 20 cents each; $\$ 18.00$ per 100 .

Hemlock Spruce $(\boldsymbol{N})$-An elegant tree with drooping branches and fine yewlike foliage: perfectly hardy and of undoubted worth and beauty. 12 to 18 inches, 30 cents each; $\$ 25.00$ per 100.

Do you live on a prairie farm? If so a word personal to rou. When we first came to Iowa nearly 45 cears ago, the ground where our nurseries are now located was bare bleak prairie. Now it is corered with fine groves of evergreens, some of them over 60 feet in height ; plots of Oruamental trees; Flowering shrubs and plants: Orchards of Apple, Plum, Cherrs; etc., ete., transforming what was in an early day a part of the Great dmerican Desert, into an rden of paradise. What we have done here, can also he done on jour place. Begin at once by cdentiof parat cou afford to next spring and then do not let a rear go by without adding to planting what jou can afford to next spring and then do not let a jear go by without adding to work of beautifying your home grounds, and any advice, coming from our long years of experience, that we can give to assist you in any way, will be gladly given 


\section{FOREST TREE SEEDLINGS.}

We have a piece of land that is especially adapted to growing strong sturdy trees, and our stock cannot be compared with the cheap stock often pulled wild from the timber and sold by irresponsible dealers.

White EIm (N)-A native tree of large size. Very popular for street and timber claim planting. Succeeds everywhere. 1 year per 100, $50 \mathrm{cts}$.; per $1000, \$ 3.00$.

Cottonwood (N)-Too well known to need description. 1 year, per 100, 50 cts.; per $1000, \$ 3.00$.

White Ash $(\mathbf{N})-1$ year, per 100,75 cts.; per $1000, \$ 6.00$.

Soft Maple (N)-A hardy, rapid growing native variety of the largest size; foliage bright green above and silvery beneath. Valuable for producing a quick shade. Excellent for street

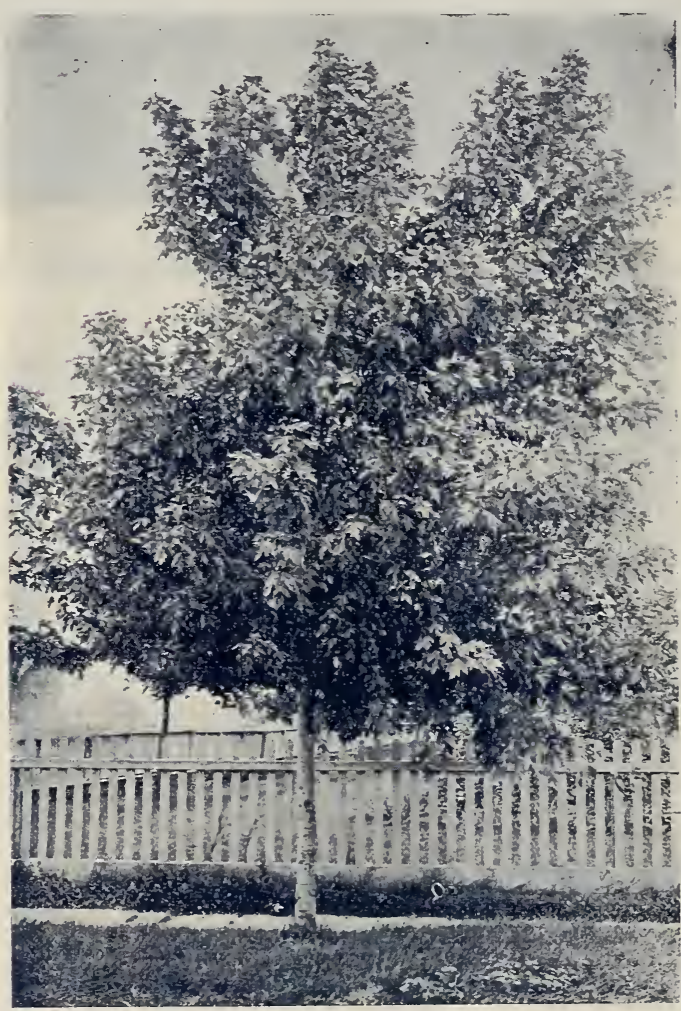

Photo. of Silver Maple, the fastest grower of all. Iakes a Dense Shade.

Crimson Rambler $(\mathbf{N})$-We find this rose all that has been claimed for it. Strong grower. Flower crimson. Very desirable. planting. Also very valuable for timber, as an acre of ground planted to this variety will keep an ordinary family in fuel after the eighth year out. Wood next to the hard woods for fuel. Very valuable. 1 year per 100,50 cts.; per $1000, \$ 3.00$.

Russian Mulberry (M), 12 to 18 inches, 75 cts. per 100.

Catalpa (M), 12 to 18 ins., 75 cts. per 100.

\section{ROSES-Climbers.}

These varieties are adapted for covering walls, trellises, etc.. etc. Their rapid growth, perfect hardiness, luxuriani foliage, immense clusters of beautiful flowers, commend them to everyone. Our roses should not be confounded with the small pot grown plants sent out from greenhouses. Ours are all field grown, and are strong bushes that will bloom at once.

Care for Roses in the North.Where the winters are long and cold, roses need winter protection. One of the best methods is to wrap the tops in old sacking, remove a little earth from one side of the plant, so that in bending the bush over to the ground, the bend will all come in the root. After doing this cover with earth, and in the spring, after danger of freezing is over, uncover and straighten up carefully, treading earth around roots. Prices for roses except where noted, 40c ea., $\$ 3$ per 10 .

Prairie Queen $(\mathbf{N})$-The we llknown climber. Flower double, beautiful pink, fading to nearly white.

Baltimore Belle $(\mathbf{N})-\mathrm{A}$ beautiful climber in pure white.

Russell's Cottage (N) - D a r k crimson, very double and full; strong grower.

Tennessee Belle $(M)-\AA$ strong, vigorous climber and free bloomer; bright rosy blush.

Yellow Rambler $(\mathbf{N})$ - Resembles the Crimson Rambler in habit of growth and flower clusters, only flower is a beautiful yellow.

Note our Key on top of page 5 . It will help you in selecting varieties. 


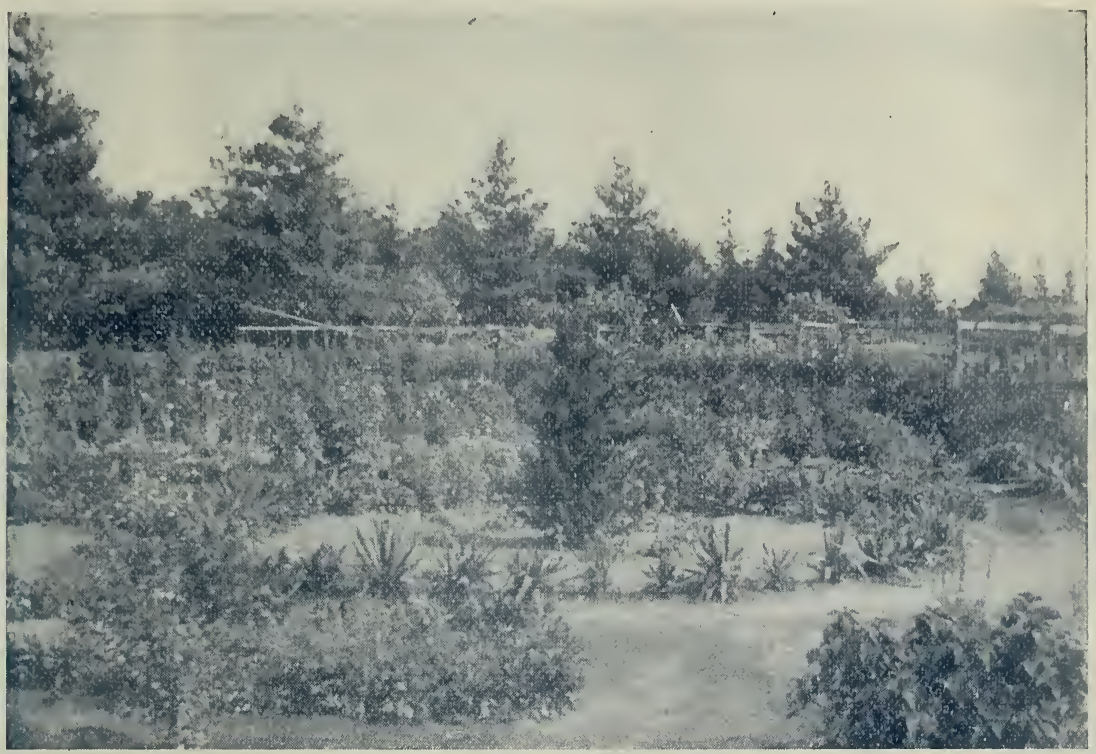

This is a view giving a glimpse of our Out-Door Flower Department. Here are found all kinds of hardy flowers, including shrubs of all kinds, vines, bulbs, etc., ete

\section{HYBRID PERPETUAL VARIETIES.}

Madame Plantier (N)-Pure white ; produced in great abundance early in the season. One of the best of the hardy white roses.

Coquette des Alps (N)-Color pure white sometimes tinged with pink. Profuse bloomer, continuing until frosts. Very hardy and beautiful.

General Jacqueminot (N)-Bright shining crimson; very rich and velvety. A well-known favorite.

General Washington $(\mathbf{N})$-This is one of the best hardy perpetuals for general planting. Color bright shining crimson, and a perfect double. Blooms first season and constantly.

Tree Roses $(\mathbf{N})$-Our tree roses are grafted on strong hardy stems at about four feet from the ground. They form fine little trees and make, when in bloom, a thing of beauty, indeed. We have them in all colors. Each, $\$ 1.50$.

\section{MOSS ROSES.}

Crested (N)-Deep pink buds, surrounded with mossy fringe. Very beautiful, free from mildew.

Luxembourg $(\mathbf{N})$-Deep crimson; fine grower.
Marshall P. Wilder (N)-Color, berry cherrv carmine; very fragrant, and one of the finest bloomers.

Mrs. John Laing (N) - A very f ree bloomer, commencing early in the season and continuing until fall. Color a soft, delicate pink.

Ulrich Brunner $(\mathbf{N})-$ Flowers large and full. Cherry color.

Rosa Rugosa (N) - A very hardy class of roses coming into popular favor. We have two varieties, one with white flower and one with bright crimson. This variety went through the winter of 1899 without protection, and was not injured in the least.

La France (M)-Delicate silvery rose, very large and full; an almost constant bloomer, equal in delicacy to a Tea Rose; the most pleasing fragrance of all roses; only a moderate grower.

La Reine (M) - Brilliant glossy rose; very large, cupped and beautiful.

Glory of Mosses (N)-A moderate grower. Flowers very large; appears to best advantage when full. Color pale rose. 


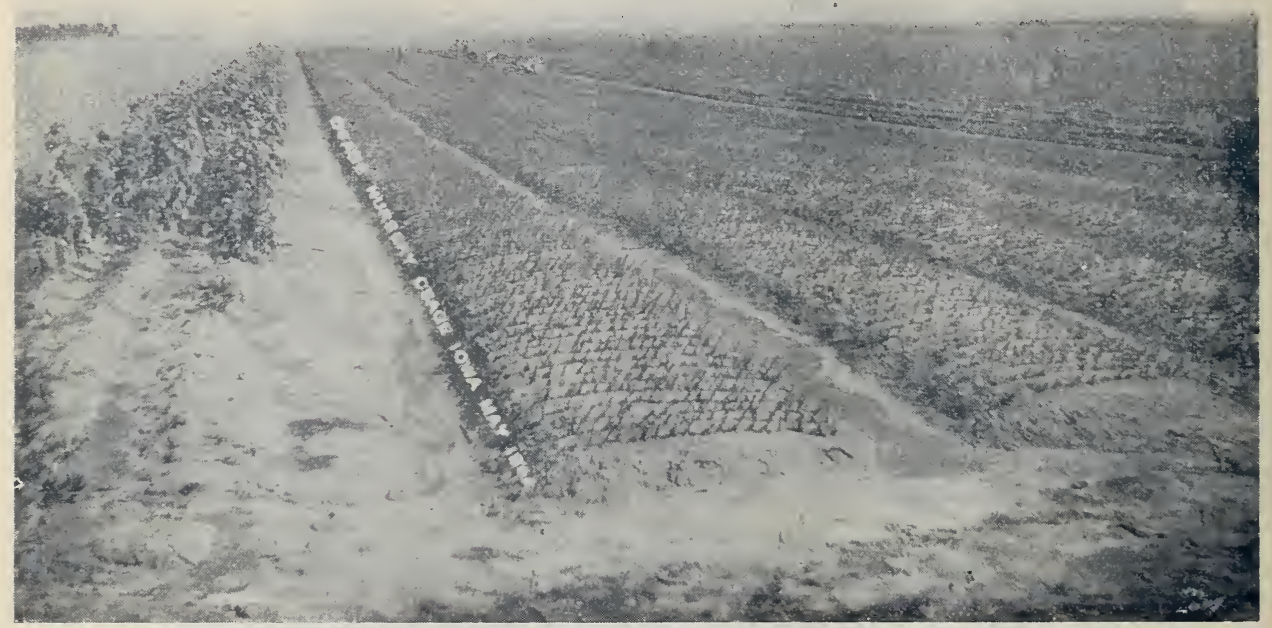

- This photo plate shows a gang of men transplanting evergreen seedlings into beds. We transplant over 1,000,000 each Jear, including alwass a goodly percentage of the beautiful COLORADO BLUE SPRUCE.

\section{HARDY FLOWERING SHRUBS.}

No one need be without flowers on the home grounds, as by planting a few of the following beautiful flowering shrubs, flowers may be had all through the summer with but little care after planting. Our assortment includes the best of the hardy varieties. We have many other varieties growing in our experimental plots and should you want anything not listed, write for prices.

$$
\text { Strong bushes, - - } \quad 40 \mathrm{cts} \text {. each : } \$ 3.00 \text { per } 10 .
$$

Berberry $(\mathbf{N})-$ Yellow flowers succeeded by red berries. Makes a very pretty effect.

Lonicera $(\mathbf{N})-($ Honeysuckle). Color pink; a climbing variety of rare beauty. Worthy of a place in every collection.

Hydrangea Paniculata Grandiflora $(\mathbf{N})-\mathrm{A}$ most beautiful shrub. Begins to bloom early in August and continues for several weeks. As hardy as the native oak, standing out over winter without protection.

Lilac (N) - The well known shrub. We have the white and purple.

Flowering Almond $(\mathbf{N})-$ Blooms early in spring, with small rose-like blossoms. Very pretty. We have them in red and white.

Snowball $(\mathbf{N})-$ Very desirable and handsome, bearing large clusters of white flowers in June.

High Bush Cranberry (N)-Bears red berries which are fine for pies and jelly.

Spirea (N)-Very hardy and easily grown, long bloomers, being in season about three months. Varieties: Van Houtte, Double Flowering, and Billardi.

Syringa (N)-An invaluable shrub of vigorous habit, very hardy, with large, handsome foliage and beautiful white flowers, resembling the orange blossoms of the south, both in appearance and in the fragrance. Should be in every collection.

Weigela (N)-An easily grown shrub. Free bloomers. White and Pink. 


\section{IIIIIIIIII)}

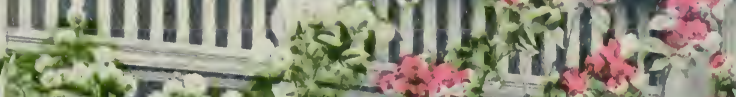

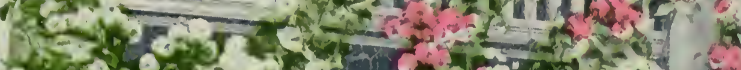

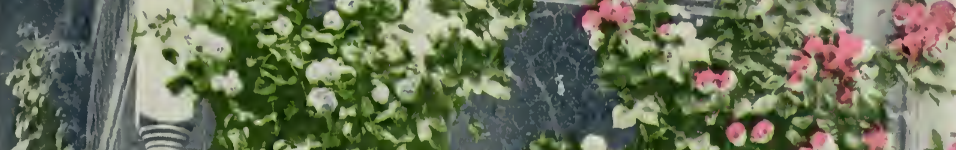

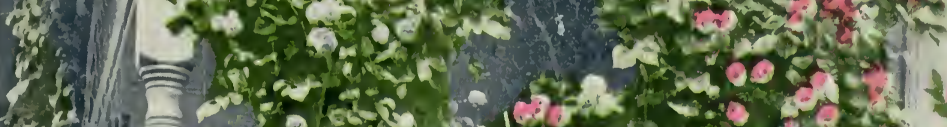
3
3

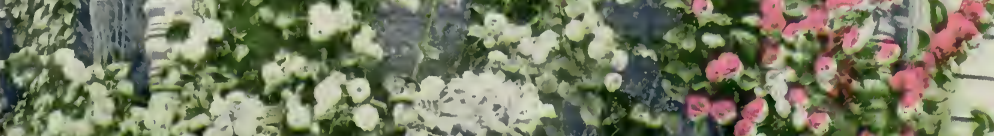

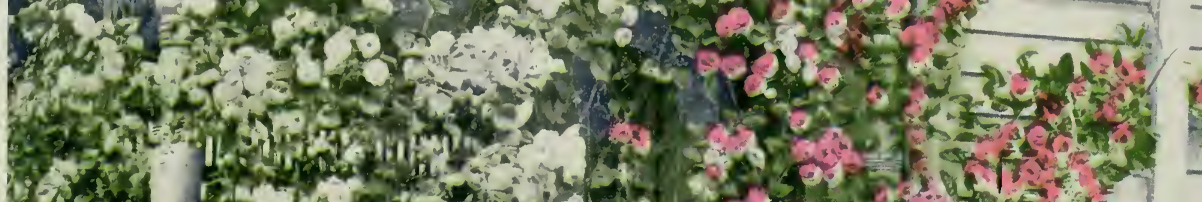

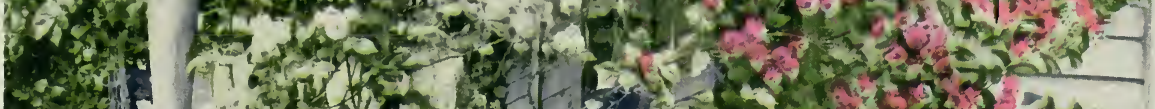

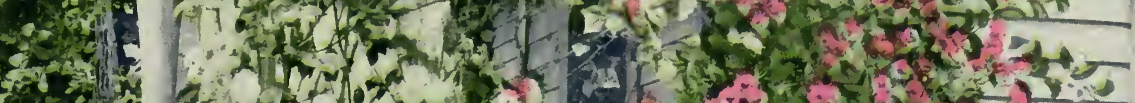

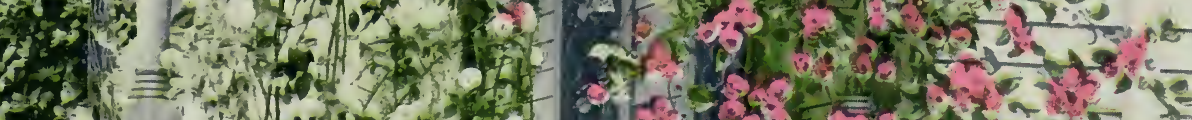

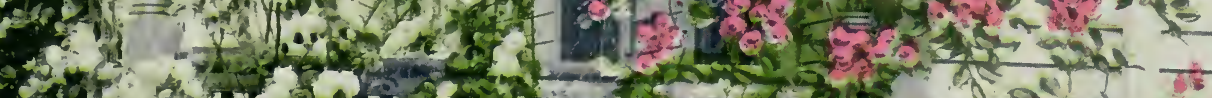

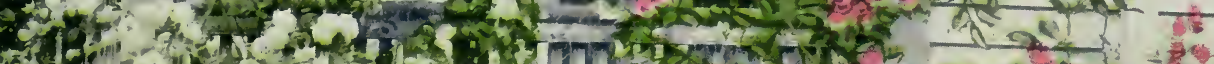
g. 5 -

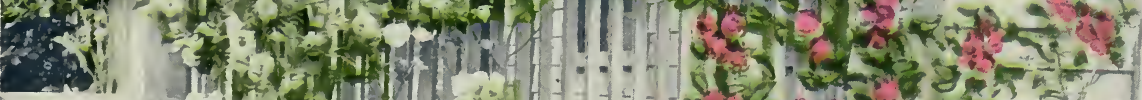

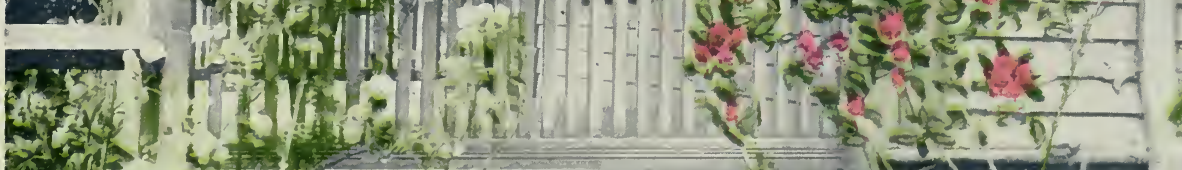
2.

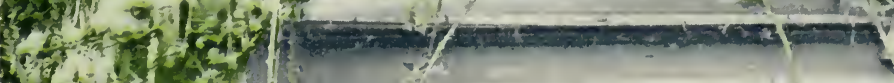

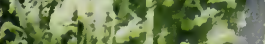

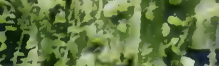

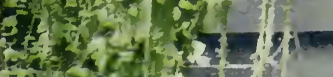
$+6>2$

and

rit

$\rightarrow$

a) 2. The $\rightarrow$

x.m. (3.). (9) $y^{2}$

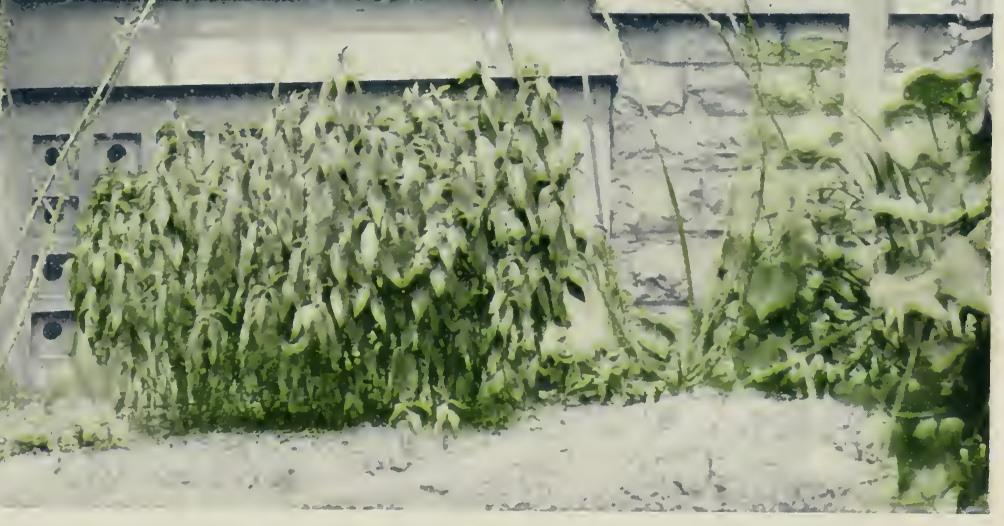

BALTIMORE BEILE AND PRAIRIE QUEEN.

[PURE WHite.]

[ROSY PINK.]

These are the best known and most popular climbers. Grown together the effect is very striking and beautiful. 


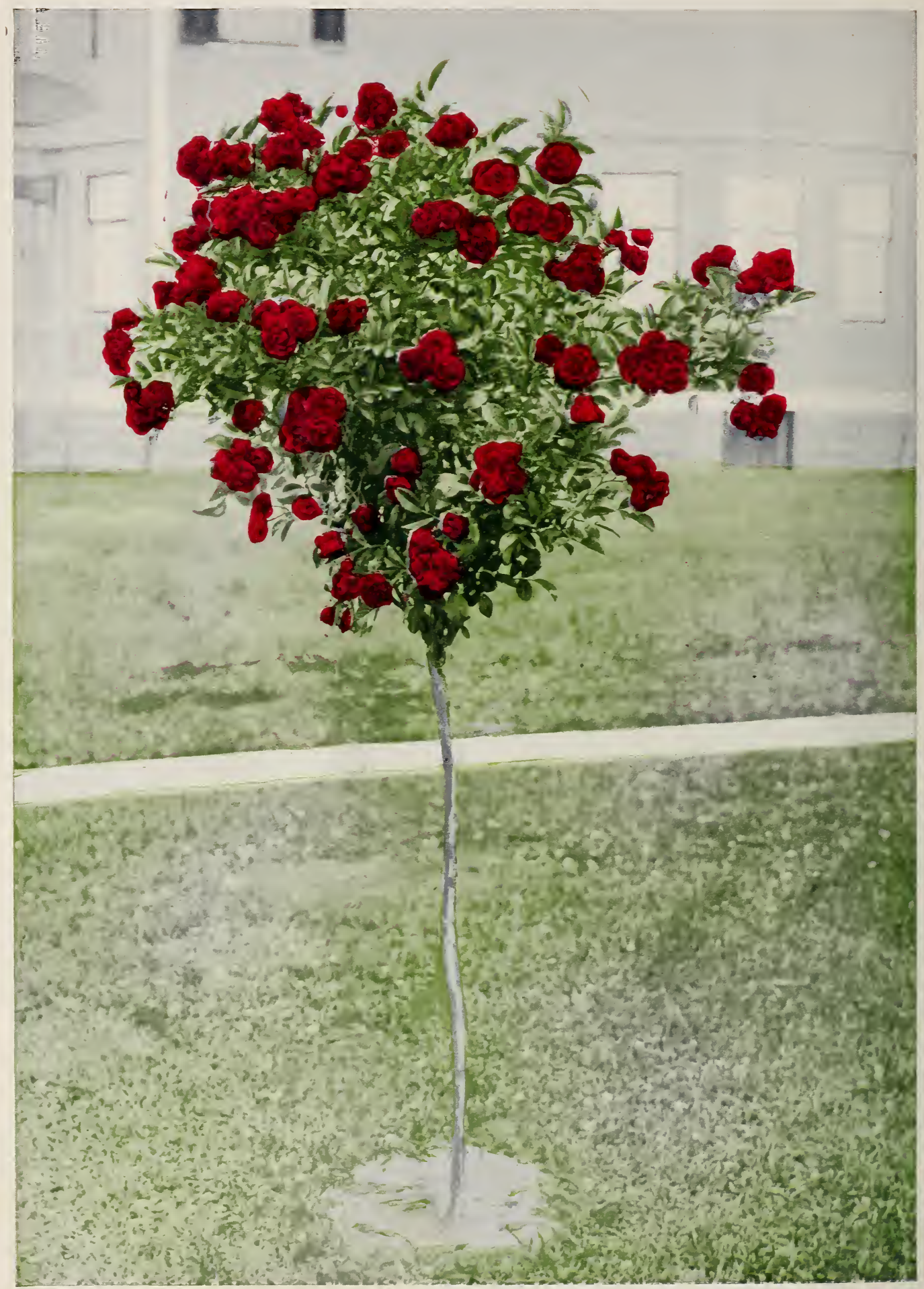

THE LOVELY TREE ROSE.

It is generally conceded that the rose is the Oueen among flowers, but when grown in Tree form they are incomparably beautiful. The fact that the blooms are larger and more perfect when grown in this way, together with the novelty of its form and growth, combine to make the Tree Rose one of the most ornamental and desirable decorative plants. Grown on native stock and perfectly hardy. May be trimmed into any desired form. 


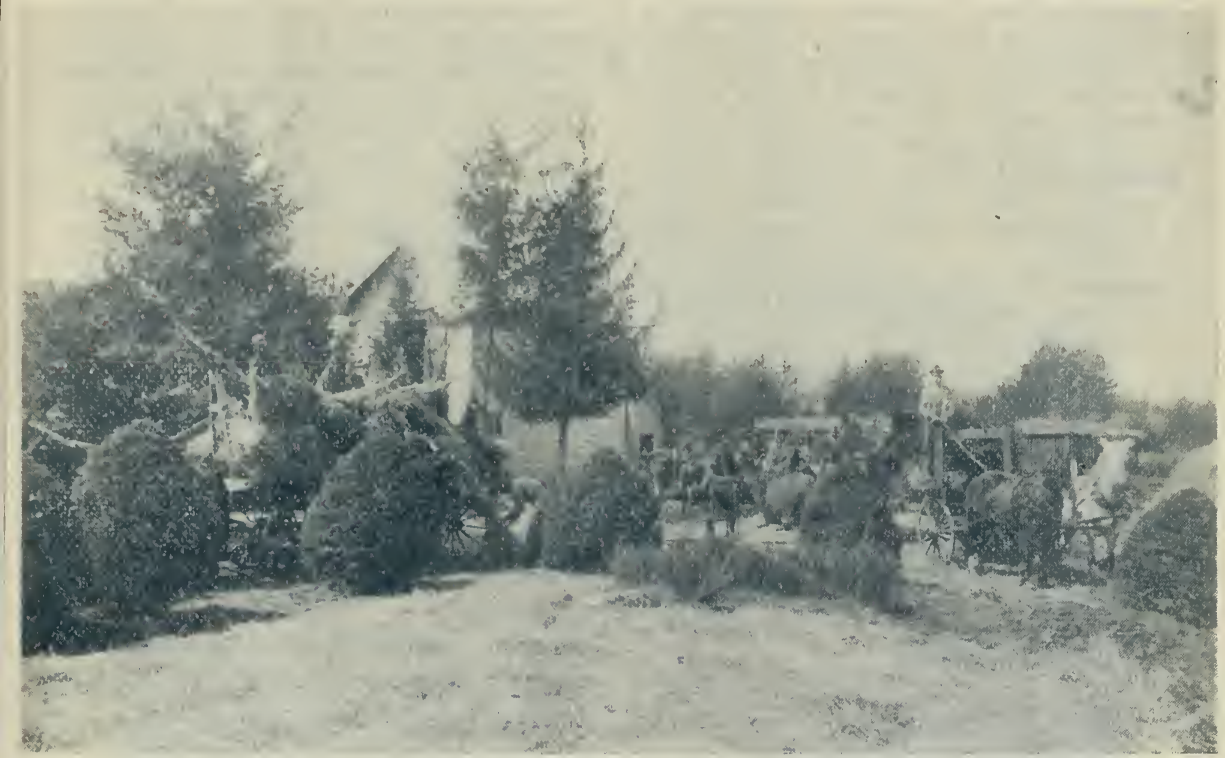

Overflow from Packing House Spring 1899. Since then we have added large storage and packing cellars in which all stock is handled without danger of getting dry.

\section{CLIMBING OR TRAILING SHRUBS.}

Clematis-We give much attention to this magnificent family of climbers. Nothing is more showy than vigorous plants of these climbers, which are adapted to any situation. They need rich soil, and are benefited by heavy mulching in summer and fall. Each, 75 cents ; $\$ 5.00$ per 10 .

Henryi (M)-New, and one of the best perpetual hybrids; of robust habit, and a free bloomer. Color white, and fluwers large and showy.

Jackmanni (M) - Probably the best known, and was the means of bringing this family of climbers before the public. Flowers large, and of intense violet purple. A free bloomer lasting until frost.
Paniculata (N)-A new sweet-scented variety of very rapid growth, quickly covering trellises, arbors or porches with a beautiful green, glossy foliage. The flowers are of medium size, pure white, borne in immense sheets, and of a most delicate and penetrating fragrance. Flowers appear in September, when few other vines are in bloom.

Virginiana $(\mathbf{N})-A$ very strong grower, having fragrant white fluwers. This variety is very valuable for covering screens, on account of its remarkable growing properties. Flowers appear in perfect sheets of bloom.

Wistaria $(\mathbf{N})$-Very popular as a climber. Produces racemes of flowers, which make a beautiful effect. Each, 40c: per 10, \$3.00.

\section{MISCELLANEOUS.}

Hardy herbaceous plants, including Bulbs, etc., etc.

Prices, unless otherwise noted, 30 cents each ; $\$ 2.50$ per 10 .

Pæonies ( $\mathbf{N}$ )-These are beautiful, showy and easily cultivated plants, blooming from the beginning of May to the end of July. We have the best of the double flowering sorts in the following colors: White, Dark Red, Pink, Rose and the Chinese.

Do not put off planting those fruit trees another year. Order now and be sure of them. 
Dahlias $(\mathbf{N})$-The Dahlia is the grandest autumn flower we have. Nothing is its equal in any respect in September and October. The tubers should be dug in fall, and kept in the cellar over winter. We can furnish red, silver, pink, yellow and other shades.

Bleeding Heart $(\mathbf{N})-\mathrm{A}$ beautiful, hardy border plant with brilliant, rosy, heart-shaped flowers. Season May and June.

adiolus $(\mathbf{N})$ - The flowers are produced on long spikes, and are of almost every desirable color. They make a

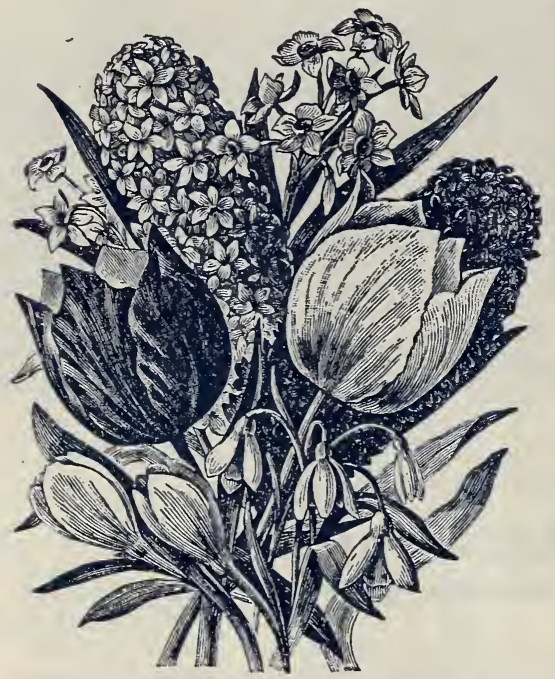

brilliant show in the flower garden, and are also much used for cut flowers.

Tuberose (M)-This flower is noted for its delicate beauty and exquisite fragrance ; the flowers are pure white, very double and wax-like, and are borne on stems two or three feet high.

Perennial Phlox (N)-The flowers of the Perennial Phlox are immense masses of bloom, from the purest white to crimson. They grow to the height of two feet, and are perfectly hardy.

IN LILIES WE HAVE THE FOLLOWING:

Lillium Auratum (N)-The bea u t if u l Gold-Banded Lily of Japan.

Lillium Excelsum (N)-Lemon Lil y. Very fine, with showy lemon colored flowers.

Lily of the Valley (N) - This is as hardy as any plant can be, and will give the best of satisfaction to all planting it.

Tulips (N) - These bulbs will thrive in almost any location, and we know of nothing which will produce such a gorgeous show of beautiful bloom during the early spring, with aslittle care and expense. Each 15 cents: $\$ 1.00$ per 10 .

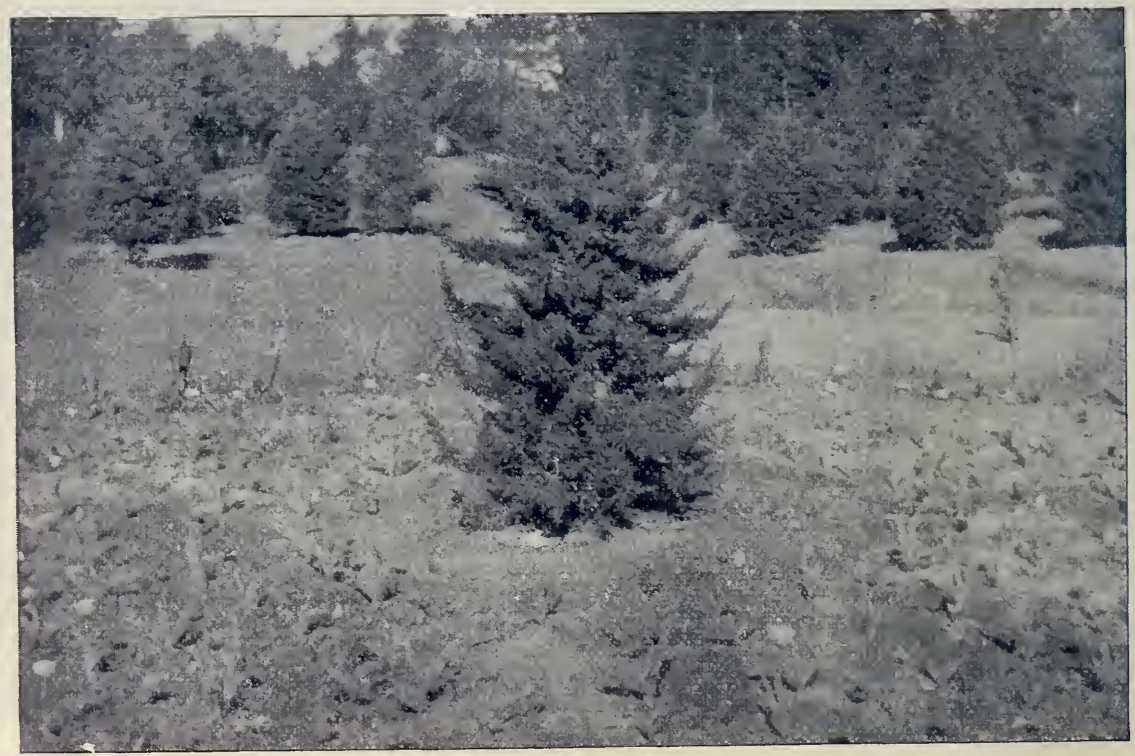

This riew was taken in the spring and shows a tulip bed which was set the previous fall. In the background may be seen fancy everoreens, specimen wind-breaks, etc. 


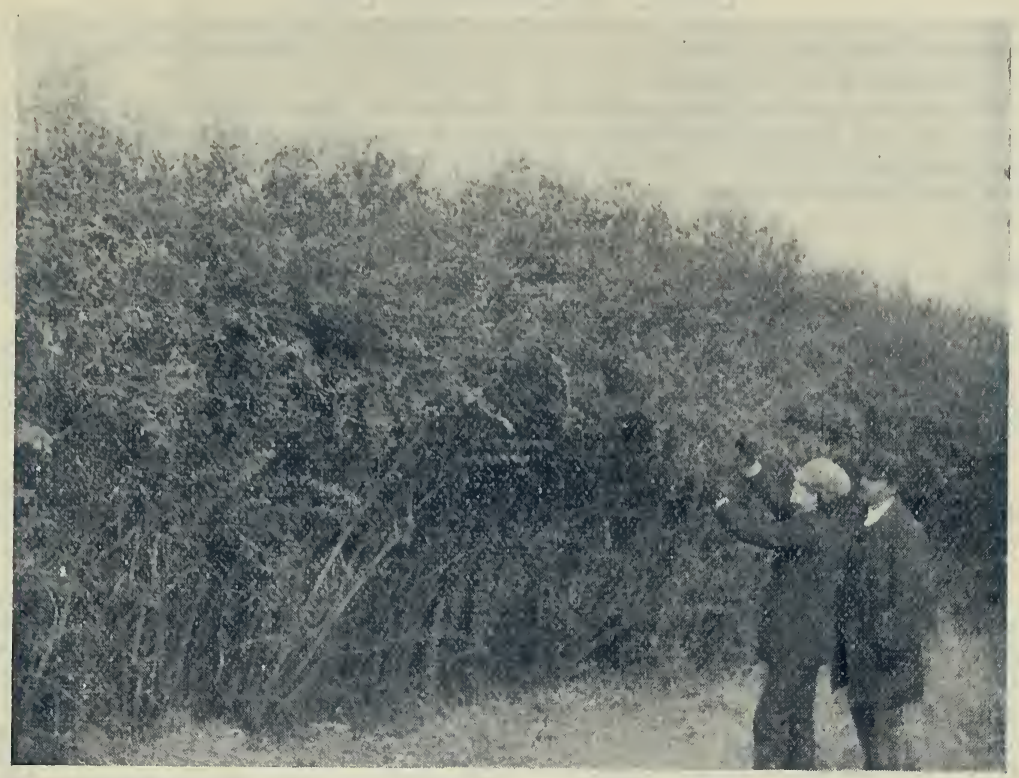

This photograph shows the Amour Berberry in use as a stock proof fence

\section{THE AMOUR BERBERRY HEDGE. (N)}

This is the ideal hedge plant of the United States. It grows to the height of from 16 to 18 feet if not trimmed, and makes a fence through which nothing can penetrate. It does not spread from the root or in any way from where it is planted. It is a fast grower, often making a growth of from 3 to 6 feet in a single year. Besides its great value as a wind-break it bears a profusion of fruit which equals currants for making jelly, wine, etc., etc. The plant is very hardy, having withstood our severe winters during the past twenty years with impunity. It is much used as an ornamental hedge, and the effect is very pretty.

Some of the AMOUR'S special points are :

1st. - Extreme hardiness.

2nd - A fast grower.

3rd.--Makes a stock proof fence.

4th.-Fruit as good as currants for jelly or wine.

5th.-Will withstand severe drouth.

6th.-Easy to transplant.

7th.-Will succeed where anything will grow.

8th.- Makes a quick and a good wind-break.

9th.- Sheared once a year, and it may be kept to any desired size, making a splendid ornamental hedge.

\section{PRICES.}

We sell the hedge shown above by the rod, using 17 plants to the rod, setting one foot apart.

2 to $2 \frac{1}{2}$ feet, per rod,

18 inches,

"6

$\begin{array}{r}-\quad-\quad \$ 1.00 \\ \hline\end{array}$ 


\section{OUR REFERENCES.}

FARMERS NATIONAL BANK.

To whom it may concern :

OSAGE, Ia., Dec 8, 1900.

With a business acquaintance with Gardner \& Son extending over the past 15 years we feel justified and take pleasure in recommending them to the public as honorable and reliable business men. We feel safe in saying that any and all orders received by them or their agents will be faithfully and carefully filled.

K. J. JOHNSON, Cashier.

OSAGE NATIONAL BANK.

To whom it may concern :

OsAGE, Iowa, June 27 th.

After an acquaintance of more than twenty years with Messrs. Gardner \& Son of this city, it is a pleasure to recommend them to the public as honest. reliable men. Any representations made by them or their agents will be faithfully performed.

J. W. ANNIS, Cashier.

We have thousands of letters on file, coming from PLEASED CUSTOMERS, from all parts of the United States. Want of space forbids printing but a few of them here. The following are fair samples :

Mento, N. DaK., 5-18-1900.

DearSirs :- I received the trees some days ago and was well pleased with them.

A. E. MCKAY.

BROWN'S VALLEY, MinN., 5-8-1900.

Gentlemen:-The trees came to hand in very good shape.

\section{J. D. BREWSTER.}

Kimball, S. Dak., Oct. 19, 1900.

The stock I received from you was all in excellent condition. I will order more for another spring. M. MARTY.

CHICAGo, ILL., 9-29-1900.

Stock arrived last spring in good condition and has made a good growth this season. EDWARD UIHLEIN.

\section{NORMAN, OKLA.}

I received my bill of trees all right. I send many thanks.

\section{SAMUEL SAMSON.}

MAUSTON, WIS., 11-5-1900.

I have received nursery stock in good shape. Thanks for same.

HERB. W. CARTER.

GUELPH, CAN., 11-10-1900.

Gentlemen:-The trees from you arrived yesterday, having been three weeks on the road. They were, however, very carefully packed, and reached here in good condition, and I am pleased with the appearance of the stock.

PROF. H. L. HUTT,

Ontario Agric. College.

SMith CENTRE, KAN., 11-õ-1900.

Received the trees and bulbs in good shape and have heeled them in. I am well pleased with them.

$$
\text { EMILY BYERS. }
$$

Bladen, Neb., 11-12-1900.

The nursery stock and flowering bulbs came all right and in good shape. W. D. WYMAN.

NEW CAMBRIA, Mo., 11-14-1900.

Enclosed find check for bill of trees received on Nov. 6th in good condition. W. T. JONES.

\section{OFFICE OF CRITTENDEN LAND} AND CATtra Co.

Crittenden, Santa Cruz Co., Arizona. Messrs. Gardner \& Son,

Osage, Iowa:

Gentlemen :-Nursery stock came through in good condition, about 20 days on the road. Have everything set out and in good soil.

R. R. RICHARDSON, Pres.

FT. Thomas, ARIzona, 5-31-1900.

I heeled in the stock as per directions, and found it in good shape this spring. JOHN REED.

WESTERN Grove, Ark., 5-23-1900. Stock was received last fall in good condition, and I heeled it in over winter. It came out $O . K$. this spring and is looking nicely now.

$$
\text { DR. G. W. FLOYD. }
$$

LOS ANGELES, Cal., 5-วั-1900.

Enclosed find draft for payment of bill. Trees arrived Wednesday and appear to be in excellent condition. It may be we will want a great many more another season.

J.F. MENDENHALL,

Sec'y Board of Park Commissioners.

We have a 32 years' record behind us in the nursery business and pleased customers from Maine to Arizona. Why? Because we always aim to grow the best of Hardy Stock and have it reach our customers in the best of growing condition. 


\section{How to Get $\$ 10$ Worth of Hardy Nursery Stock for a Few Minutes of Your Spare Time.}

Secure signers for the five coupons on this sheet, as per terms given on each coupon, which entitles the signer to the Special Advertising Collection of Hardy Nursery Stock as listed thereon. For your trouble in doing this you may select from this catalogue, $\$ 10.00$ worth of our best stock, your own selection, and at proper time we will ship all orders carefully packed, to your address, making freight cheaper than if all were sent to separate addresses.

Terms : Cash with order. Collect the $\$ 2.00$ and the 25 cts. additional for freight charges, from each person as they sign the coupon, or if you prefer you can advance the $\$ 10.00$ and the $\$ 1.25$ additional for freight charges yourself, and then collect from the parties when the stock is delivered, thus getting your money back and having the $\$ 10.00$ worth of stock with freight prepaid for your trouble.

Upon receiving this sheet with remittance we will at once mail to each signer of a coupon a catalogue containing the coupon offers, thus giving them the same chance to secure the $\$ 10.00$ premium that you have had.

We use this novel method to introduce our Hardy Nursery Stock in your locality, knowing from experience that other orders will follow and a permanent customer will be secured from each purchaser of a coupon order.

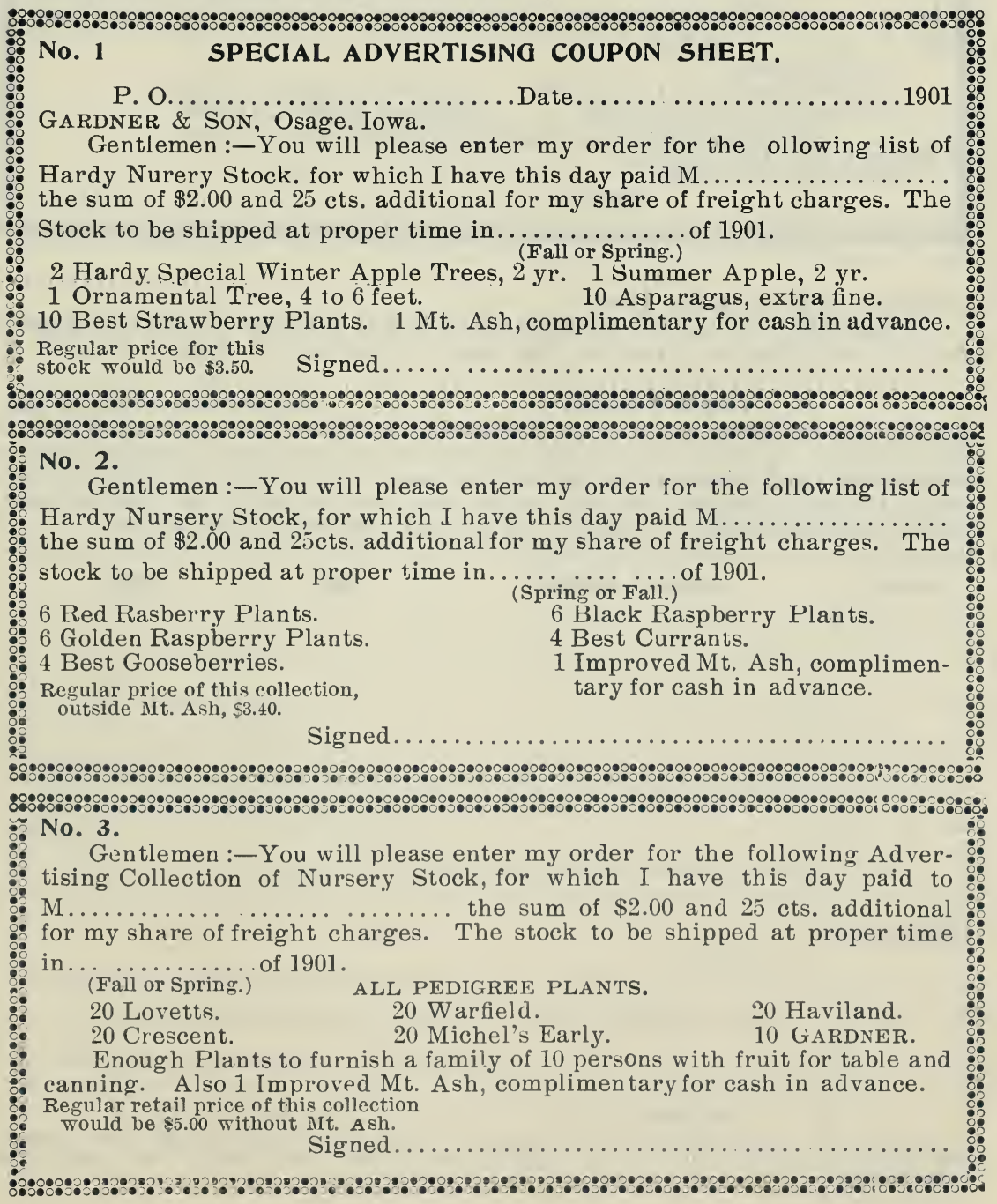




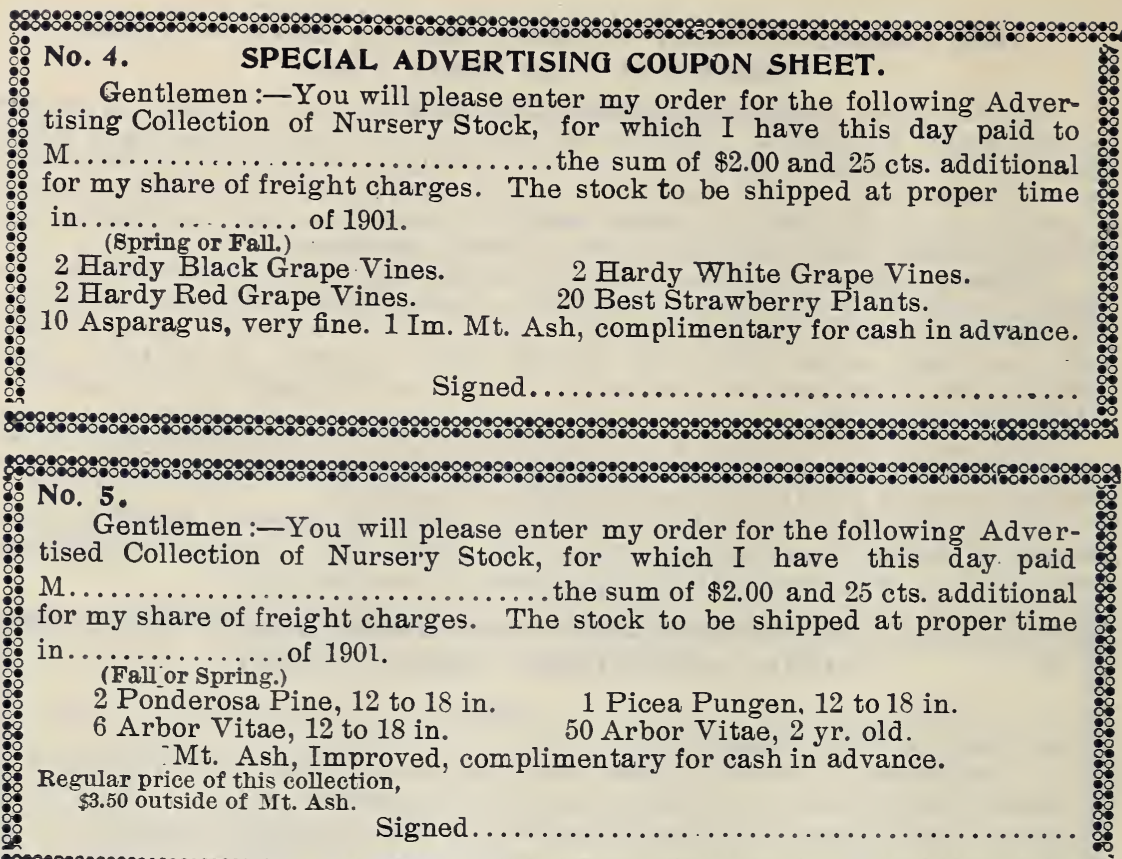

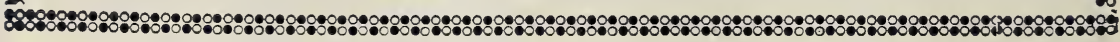

P. O...

GARDNER \& Son, Osage, Iowa.

Gentlemen:-Please find enclosed $\$ 11.25$ in full payment for the five Special Advertising Offers as given on this sheet, with freight charges prepaid to Your R. R. Station.

As per your offer you may send me the following bill of stock, amounting to $\$ 10$ at prices as named in this book, which I agree to accept in full payment for my services in placing the five coupon offers and attending to delivery of same. Ship all of the stock to me, with all freight charges prepaid, taking due care in tieing and labeling each bundle so that the different orders may be easily separated upon arrival.

\begin{tabular}{c|c|c|c|c|c|}
\hline \hline Quantity. & NAME OF VARIETIES. & SIZE. & \multicolumn{2}{c}{ PRICE. } \\
\hline & & & & \\
\hline & & & & & \\
\hline
\end{tabular}

REMARKS

\section{SIGNED}

Select from Catalogue and fill in above any stock that you want to the amount of \$10. Should you wish to order more thau the $\$ 10$ worth, use the regular order blank on next page for the extra amount. 


\section{Our Patrons will greatly oblige us by using this}

\section{ORDER SHEET.}

\section{OSAGE NURSERIES,}

\section{GARDNER \& SON, • • Props.}

OSAGE, IOWA.

Do Not Write Here.

No

File

Date

Amount Rec'd

$\$$

Name

Write plainly, giving your full name.

Post Uffice

County

Staite

R. R. Station

If different from P. O

Amount Enclosed \$

Date 190

To be shipped in Spring or Fall

by

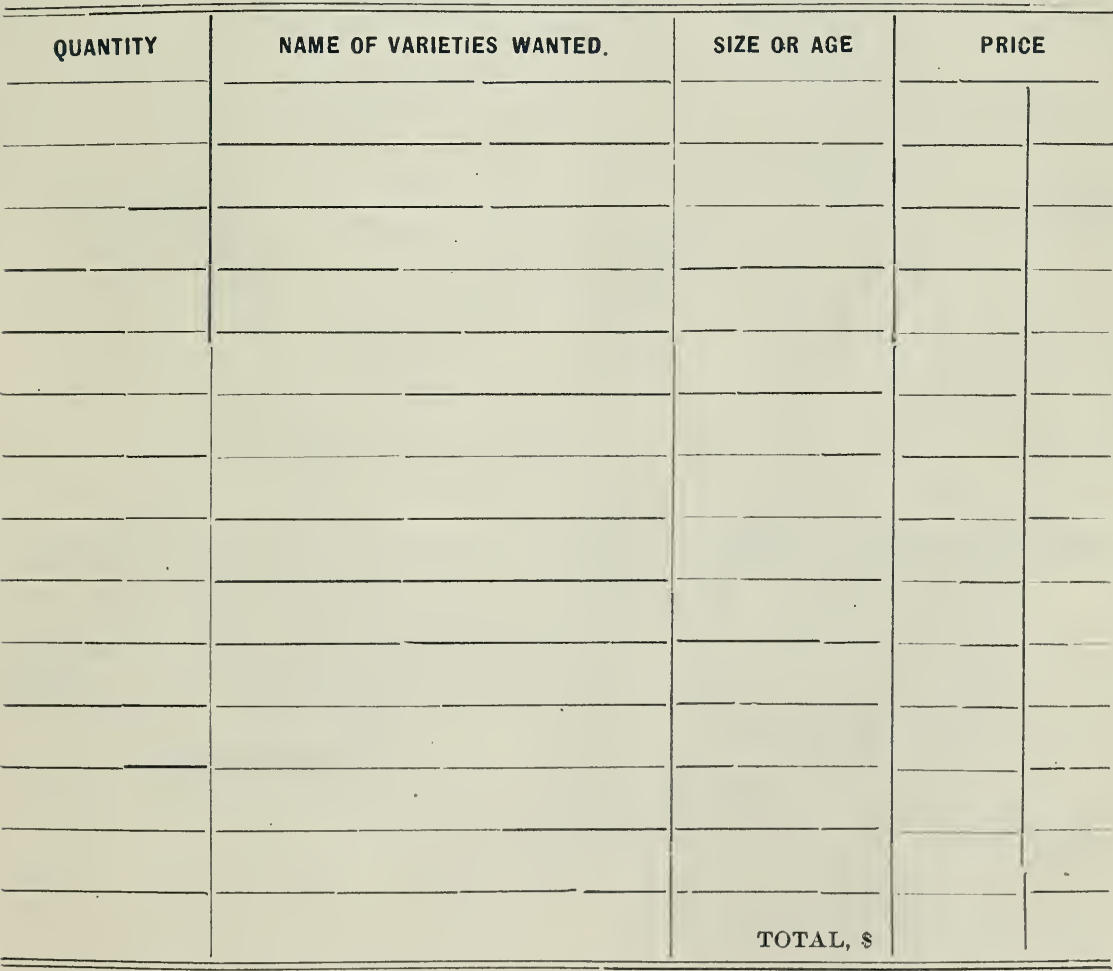

If this order was given in response to our advertisement, please give name of paper

If not to any paper, to whom or what do we owe credit for your orders? 
VERY IMPORTANT.-No matter how of ten you write to us, always give your full address and sign your name the same each time.

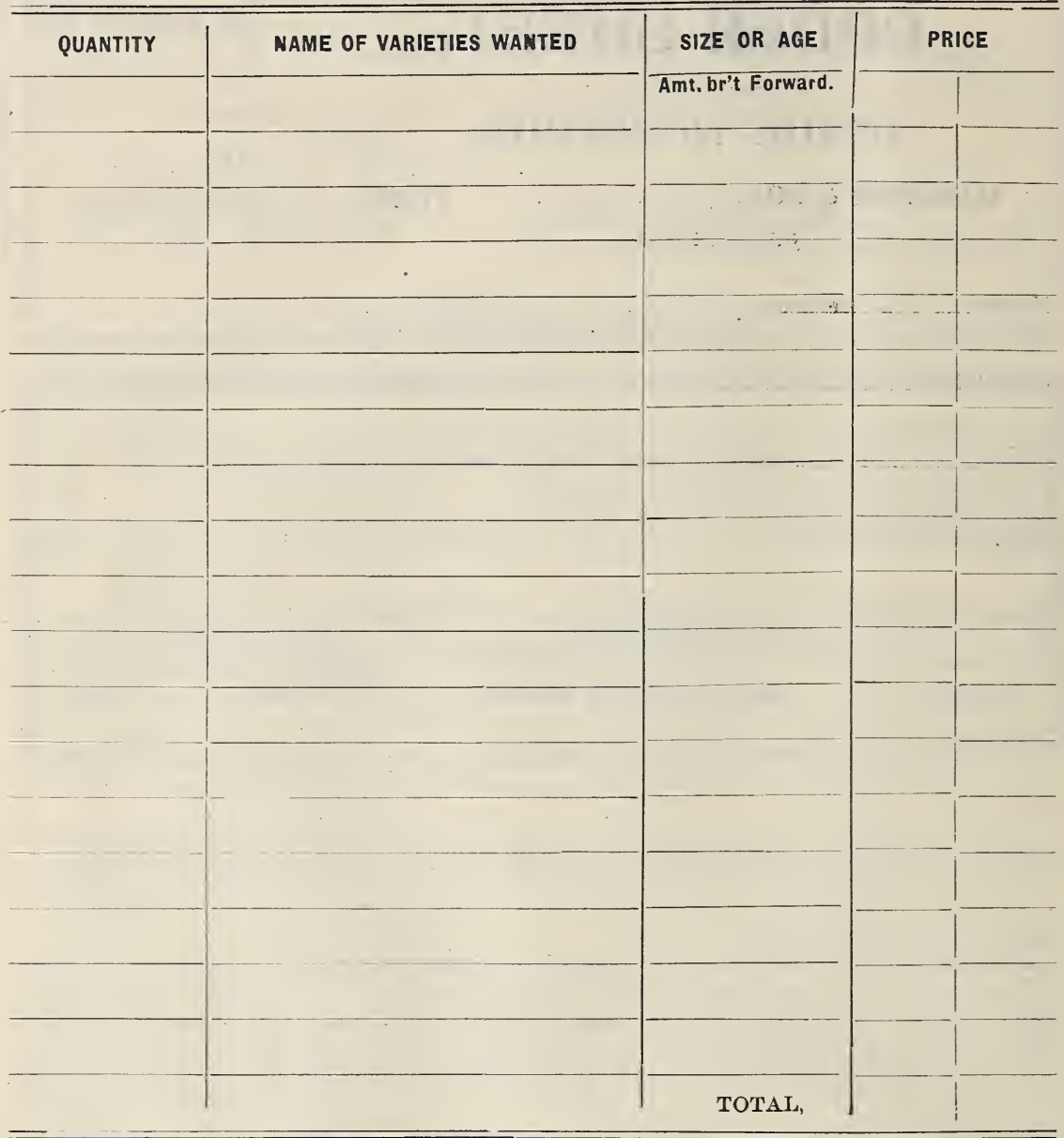

Orders only PARTLY Filled, instead of sending other good sorts, or another size - this often causes disappointment. For we take it for granted customers wish to plant or test certain sorts and know what they want; and yet if they knew we were sold out of a variety ordered they would of ten accept another, rather than be wholly disappointed. So, when orders cannot be filled exactly, we use our best judgment as to sending as nearly similar sorts as possible, or another size. But your first choice will always be sent if in the Nursery.

We wish, however, to fill orders to your entire satisfaction; so please state whether we shall refund the money sen.t, or what to send in case we should be out of any size or sort ordered.

Sizes : If my order cannot be filled, either in whole or in part, with size wanted, my next preference is : .........size. Next........size. Next........size. Sorts : If any sorts ordered cannot be furnished, some of the following varieties would be acceptable:

If above does not meet the case, kindly write "Yes" or "No" in the following blank: If order cannot be filled to the letter, shall we exercise our best judgment and discretion in the matter? 
STATE OF IOWA-CERTIFICATE OF NURSERY INSPECTION.

This Is To Certify, That the Growing Nursery Stock and premises of the Osage Nurseries, Gardner \& Son, Proprietors, situated in Osage, County of Mitchell, State of Iowa, have been inspected according to the provisions of Chapter 53 of the Acts of the Twenty-seventh Assembly, and that no indications have been found of the presence of San Jose scale or other dangerous insect or plant disease.

This certificate invalid after June I, Igor.
Certificate No. 59 .

H, E. SUMMERS, State Entomologist.

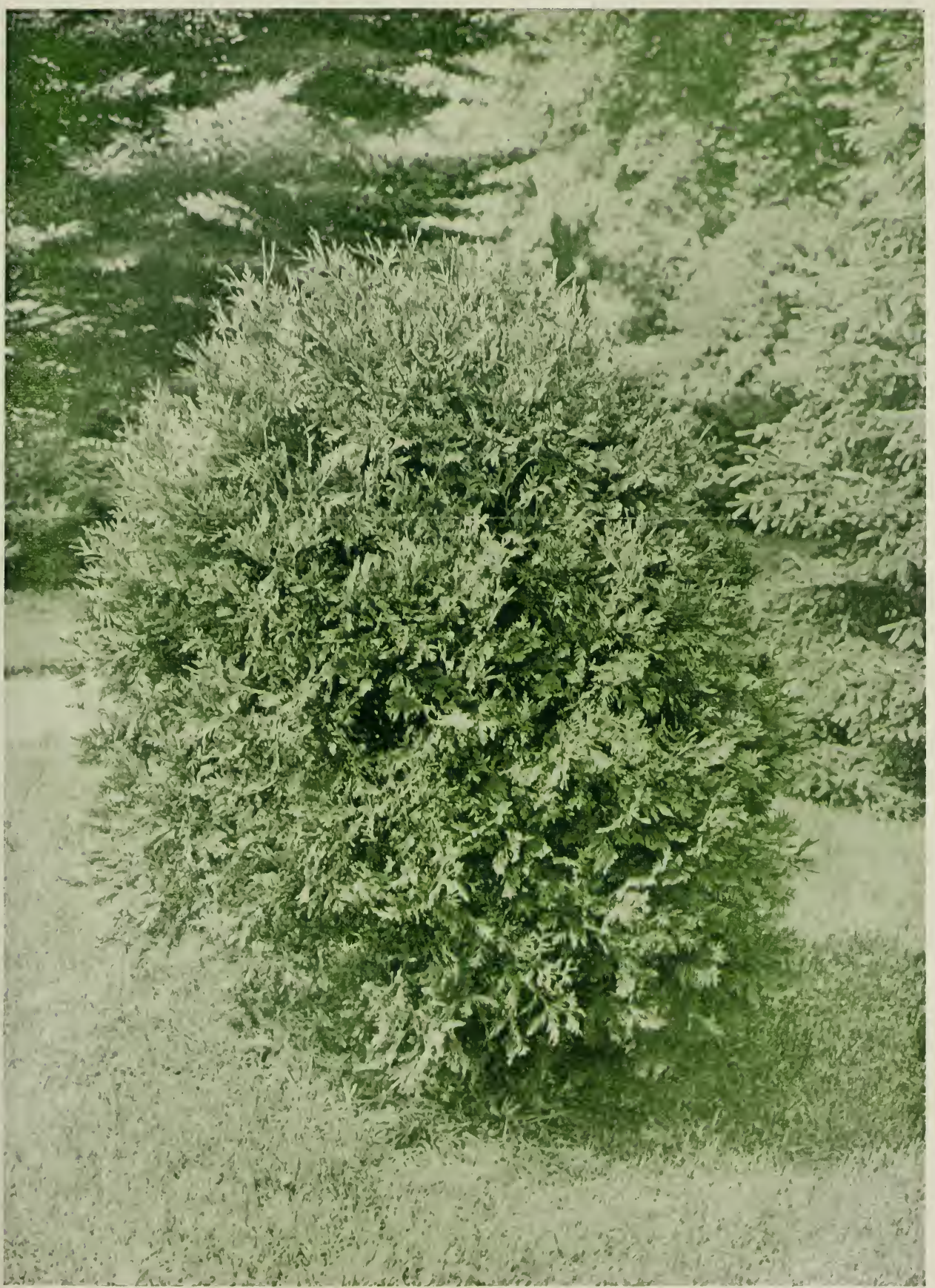

IVHITE CEDAR (ARbor Vitk).

Very suitable for hedging and ornamental planting.

[See page 20 for prices ] 


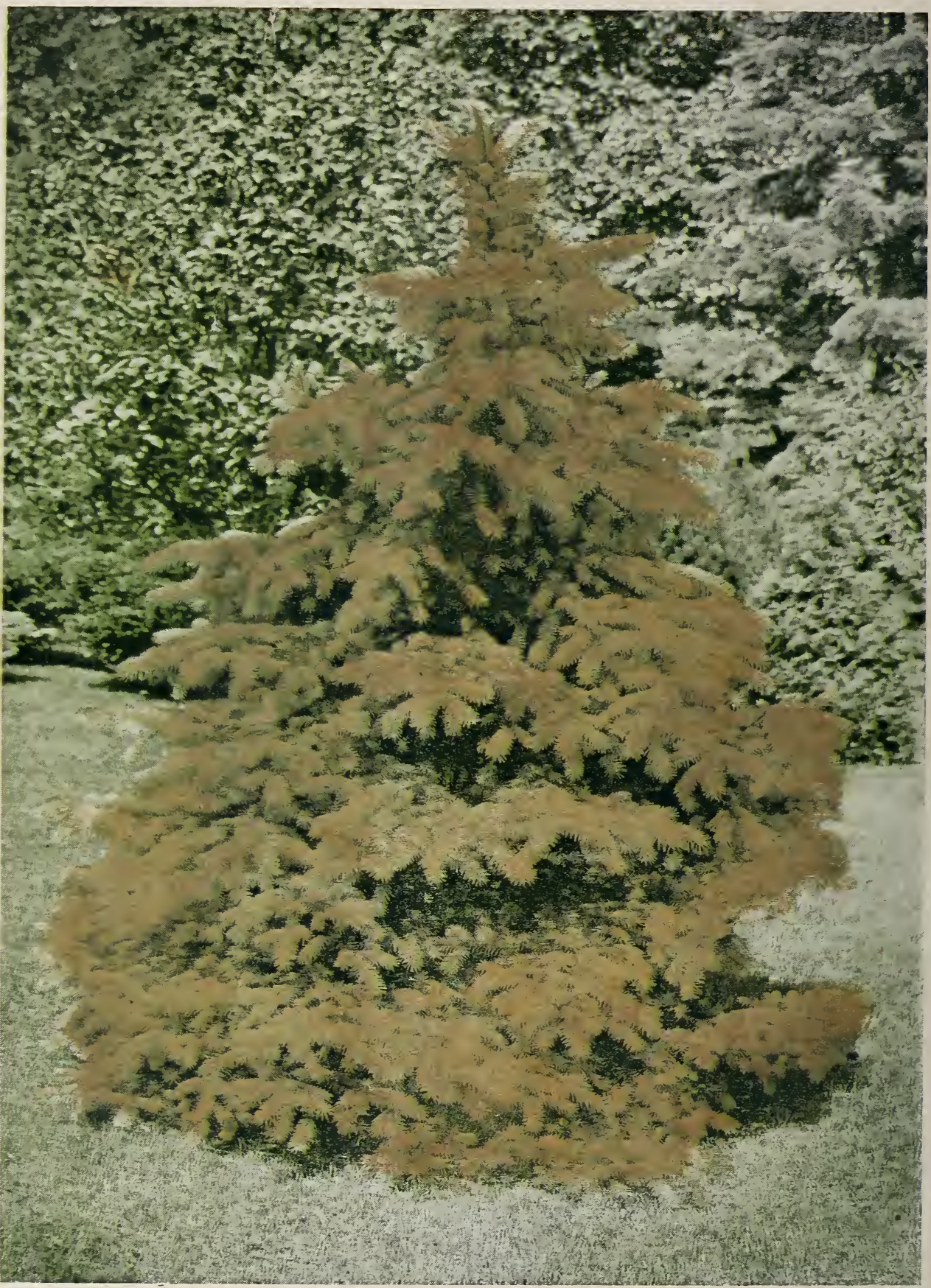

COLORADO BLUE SPRUCE.

(Picea Pungens.)

For fancy lawn, park, 丞and cemetery planting. 